Division of Geological \& Geophysical Surveys

PRELIMINARY INTERPRETIVE REPORT 2012-1c

\title{
RECONNAISSANCE INTERPRETATION OF 1978-1981 PERMAFROST, ALASKA HIGHWAY CORRIDOR, TETLIN JUNCTION TO CANADA BORDER, ALASKA
}

by

Richard D. Reger, Trent D. Hubbard, and Patricia E. Gallagher

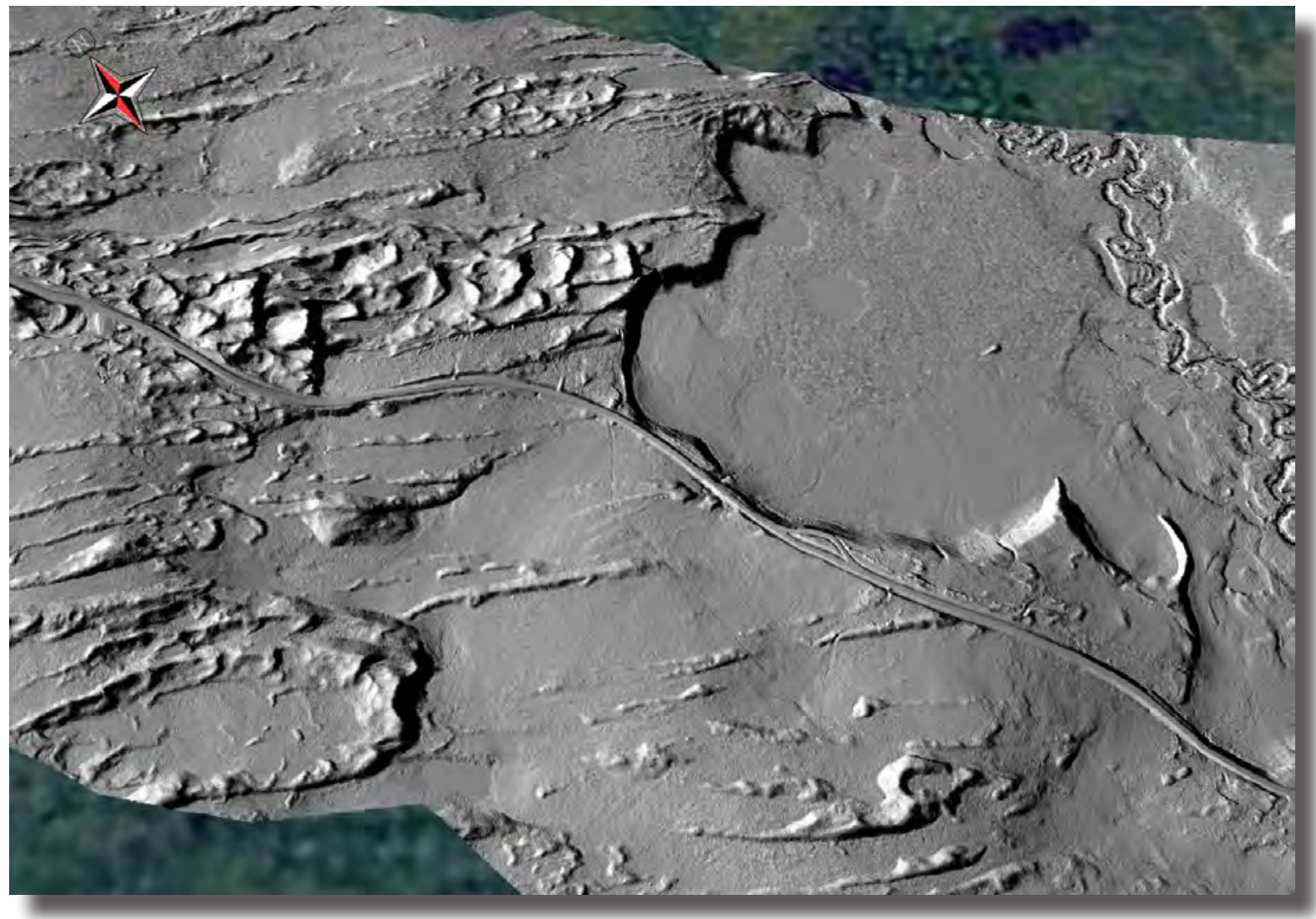

Oblique lidar hillshade image illustrating frozen sand dunes along the Alaska Highway, northwest of Gardiner Creek in the Nabesna Quadrangle.

April 2012

Released by

STATE OF ALASKA

DEPARTMENT OF NATURAL RESOURCES

Division of Geological \& Geophysical Surveys

3354 College Rd., Fairbanks, Alaska 99709-3707 



\section{CONTENTS}

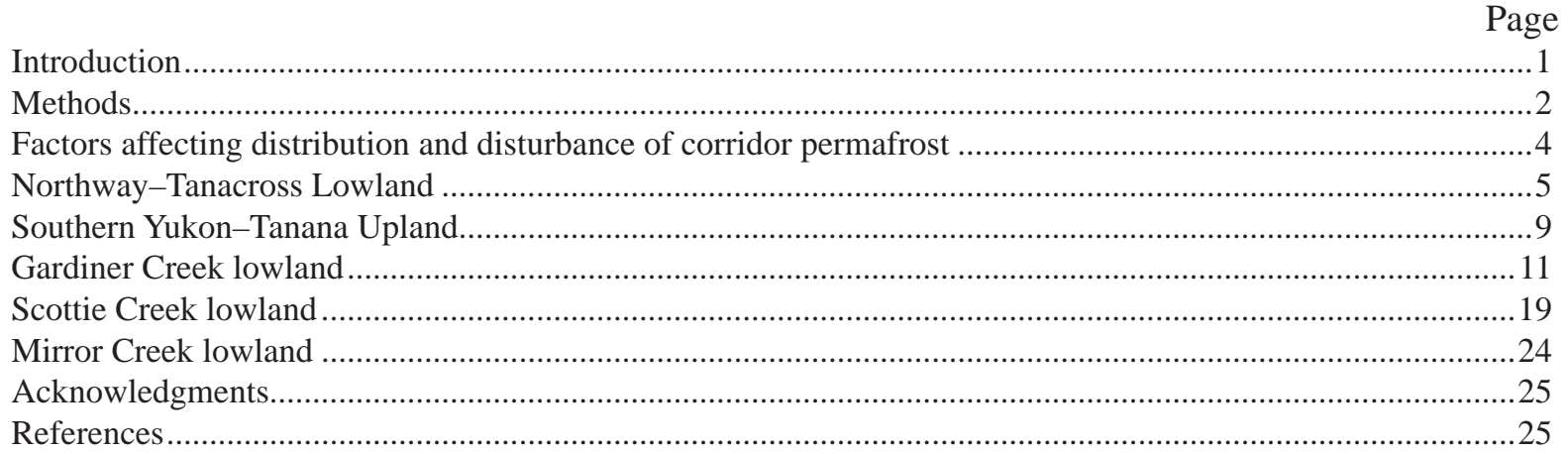

\section{TABLE}

Table 1. Gravimetric soil moisture contents in samples of eolian and retransported eolian deposits in pipeline corridor segment 3, Tanacross and Nabesna quadrangles.

\section{FIGURES}

Figure 1. Location of study area in Tanacross and Nabesna quadrangles and sites discussed in report...........1

2. Segment of multilayer inversion model (EM1DFM) 15290 (Burns and others, unpublished data) showing relations of permafrost to fine-grained valley fill in eastern Desper-Scottie creeks lowland

3. Generalized ground-temperature profile in area of permafrost ................................................4

4. Factors influencing expansion of thaw lakes through bank recession .......................................6

5. Evolution of thaw lakes in Nabesna-Chisana rivers area, Northway lowland, according to

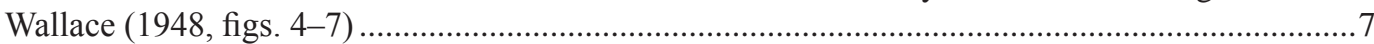

6. False-color infrared aerial photograph showing natural levee-lake delta complexes that intricately divide former large slackwater lake basin into numerous sub-basins, including Eliza Lake and Yarger Lake, northeastern Nabesna D-2 Quadrangle ....

7. Typical sedge tussock and scattered black spruce vegetation on shallow continuous permafrost, floor of upper Ladue River valley, southern Tanacross B-3 Quadrangle.

8. Pair of open-system pingos on perennially frozen lower southern slope of upper Ladue River valley, southern Tanacross B-3 Quadrangle.

9. Evolution of open-system pingos (developed from Holmes and others, 1968) ..........................12

10. Aerial view toward northwest of large, arcuate, retrogressive failure that intersected Alaska Highway near milepost 1267 and required rerouting in 2004 ................................................13

11A. Aerial view toward southwest of complex linear and arcuate ground cracks and scarps produced by active landsliding in former roadbed of Alaska Highway near milepost $1267 \ldots . . . . . . .14$

11B. Active landslide scarps offset abandoned roadbed of Alaska Highway near milepost 1267 .........14

11C. Live spruce trees tilted toward head of active landslide in thawing retransported silt near Alaska Highway milepost 1267

11D. Live spruce tree split by widening tension crack in active landslide in thawing retransported silt near Alaska Highway milepost 1267

11E. Tilting and compression of willow shrubs by advance of active landslide in thawing retransported silt near Alaska Highway milepost 1267

12. Sketch of culvert elements in one of ten open-duct systems installed in 1983 near the northern and southern margins of the thick roadfill at Alaska Highway milepost 1240

13. Vegetated southern flank of thick roadfill at Alaska Highway milepost 1240.3 in southwestern Nabesna D-1 Quadrangle, showing tops of vertical corrugated culverts and inclined end of horizontal culvert with adjustable metal cover. 
14. Damage to Alaska Highway caused by differential settlement of thick roadfill at milepost 1240.3 .

15. Aerial view toward west of numerous thaw lakes in Scottie Creek lowland, northwestern Nabesna C-1 Quadrangle

16. Aerial view of inactive thaw lake, peat-filled thaw lake basin, and polygonal ground, Scottie Creek lowland, northwestern Nabesna C-1 Quadrangle

17. Black spruce trees tilted into large thaw lake by active bank recession, Scottie Creek lowland, northwestern Nabesna C-1 Quadrangle

8. Features related to ground ice in permafrost, Scottie Creek lowland.

19. Dense black spruce forest with numerous tilted and downed trees on crest of low mound of perennially frozen, retransported sandy silt, northeastern Nabesna C-1 Quadrangle

Aerial view of spring source for small stream draining tussock-covered lowland of perennially frozen, retransported sandy eolian silt, northeastern Nabesna C-1 Quadrangle.

Chaotic black spruce and scattered, dead balsam poplar trees in thermokarst-modified channel of small stream in northeastern Nabesna C-1 Quadrangle

\section{SHEETS (in envelope)}

Sheet 1. Reconnaissance interpretive map of 1978-1981 permafrost, Alaska Highway corridor, parts of Tanacross A-1, A-2, A-3, and B-3 quadrangles, Alaska

2 Reconnaissance interpretive map of 1978-1981 permafrost, Alaska Highway corridor, parts of Nabesna C-1, D-2, D-2, and D-3 quadrangles, Alaska 


\title{
RECONNAISSANCE INTERPRETATION OF 1978-1981 PERMAFROST, ALASKA HIGHWAY CORRIDOR, TETLIN JUNCTION TO CANADA BORDER, ALASKA
}

\author{
by
}

Richard D. Reger ${ }^{1}$, Trent D. Hubbard², and Patricia E. Gallagher ${ }^{2}$

\section{INTRODUCTION}

During 2009, the Alaska Division of Geological \& Geophysical Surveys (DGGS) conducted reconnaissance interpretive mapping of permafrost in Alaska Highway Corridor segment 3, a 19.3-km-wide corridor that straddles the Alaska Highway through the Northway-Tanacross Lowland and the southern Yukon-Tanana Upland from Tetlin Junction to the Canada border (fig. 1). Average annual lowland air temperatures vary from $-4.7^{\circ} \mathrm{C}$ at Tok to $-5.4^{\circ} \mathrm{C}$ at Northway Airport (http://www.wrcc.dri.edu/htmlfiles/ak/ak.tmp.ext.html), becoming colder southeastward.

This report and previous related reports are intended to provide preliminary information that is useful for planning more detailed, site-specific investigations that are necessary for design of future infrastructure in the Alaska Highway corridor (Reger and Solie, 2008a, b; Reger and others, 2008, 2011, in press; Reger and Hubbard, 2010a, b,).

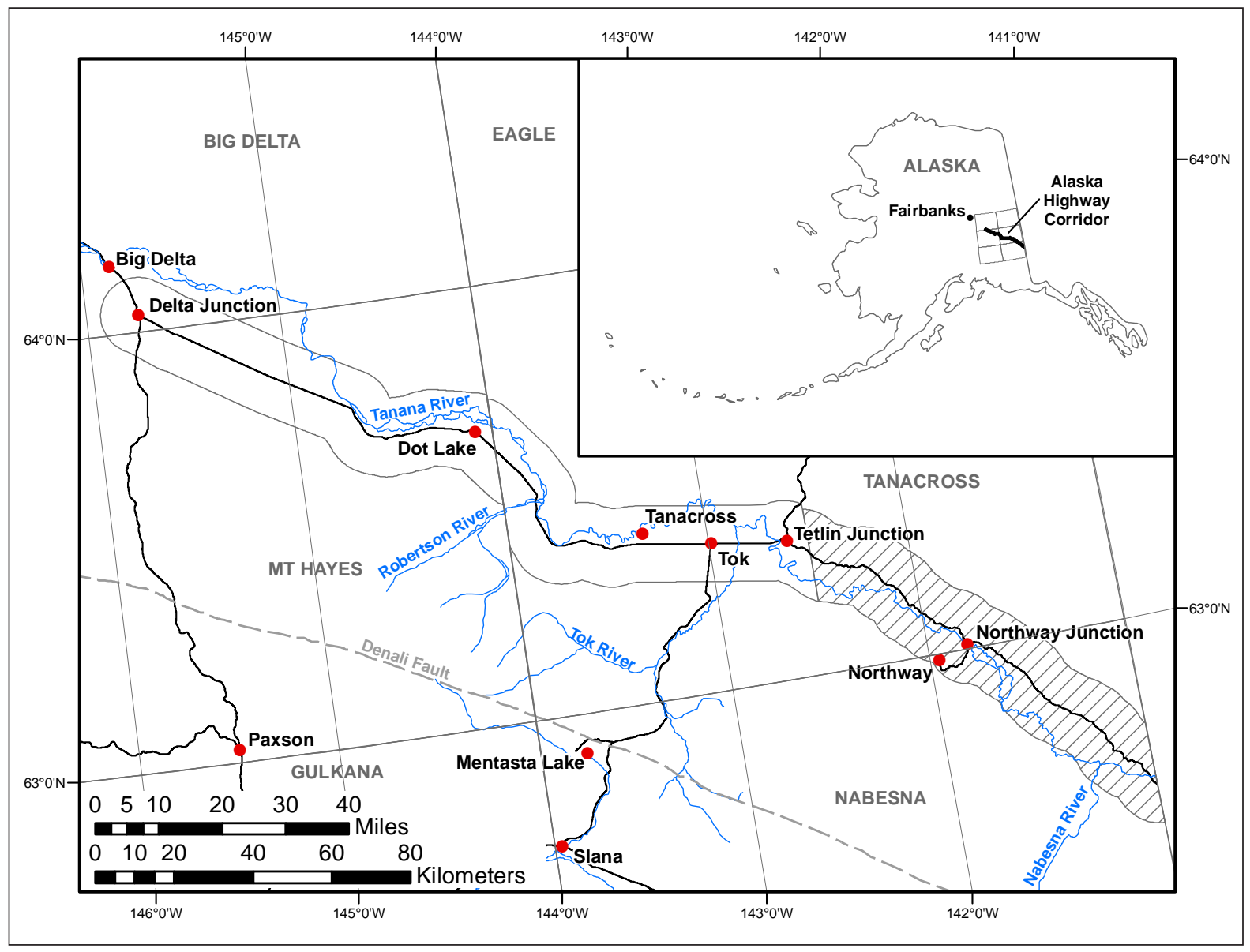

Figure 1. Location of study area in Tanacross and Nabesna quadrangles, and sites discussed in report.

${ }^{1}$ Reger’s Geologic Consulting, P.O. Box 3326, Soldotna, Alaska 99669

${ }^{2}$ Alaska Division of Geological \& Geophysical Surveys, 3354 College Rd., Fairbanks, Alaska 99709-3707 


\section{METHODS}

We initially inferred the extent of permafrost and ice content by interpreting 1:65,000-scale, false-color infrared aerial photographs taken in July 1978 and August 1981. Therefore, the units in our permafrost maps illustrate our interpretation of permafrost conditions from July 1978 through August 1981. Proxy data include vegetation, slope and aspect, landforms, geology, local drainage, and terrain features. Landforms such as open-system pingos, polygonal ground, thermokarst pits and gullies, and thaw lakes and thaw ponds are diagnostic of the presence or former presence of permafrost (Hopkins and others, 1955; Ferrians and others, 1969; Kreig and Reger, 1982). In conjunction with the reconnaissance mapping (sheets 1 and 2), we incorporated information available in the professional literature and data from a single temperature-monitoring site into our preliminary maps. During summer fieldwork in 2009, we dug numerous test pits to verify initial interpretations. After initial permafrost maps had been prepared, airborne-resistivity data became available, and we were able to compare our mapping with those data, producing map changes that better reflect local conditions (see sidebar). Our permafrost designations should be considered tentative until validated by multi-year ground-temperature measurements below the level of annual temperature variation.

Our permafrost maps have obvious limitations because they are based on data collected several years ago. The small amount of subsurface data in the vicinity of Northway was collected by Wallace prior to 1948 and by Williams prior to 1970, and in the Scottie Creek area was collected in 1982 and 1992 (Hemenway, 1994). Permafrost is interpreted primarily based on the vegetation shown in false-color, infrared aerial photographs taken at least 30 years ago, and several extensive wildfires had altered the surface vegetation across sections of the corridor just prior to the photography on which this study is based. The magnitude of change in the proposed corridor has not been documented by comparisons of aerial photographs taken before or after 1978-1981. However, based on the airborne-resistivity sections, we believe that these changes have been most extensive on the floor of the Tanana River valley, where fine-grained sediments with moderate to high ice content are widespread and large volumes of groundwater flow through lowland alluvium.

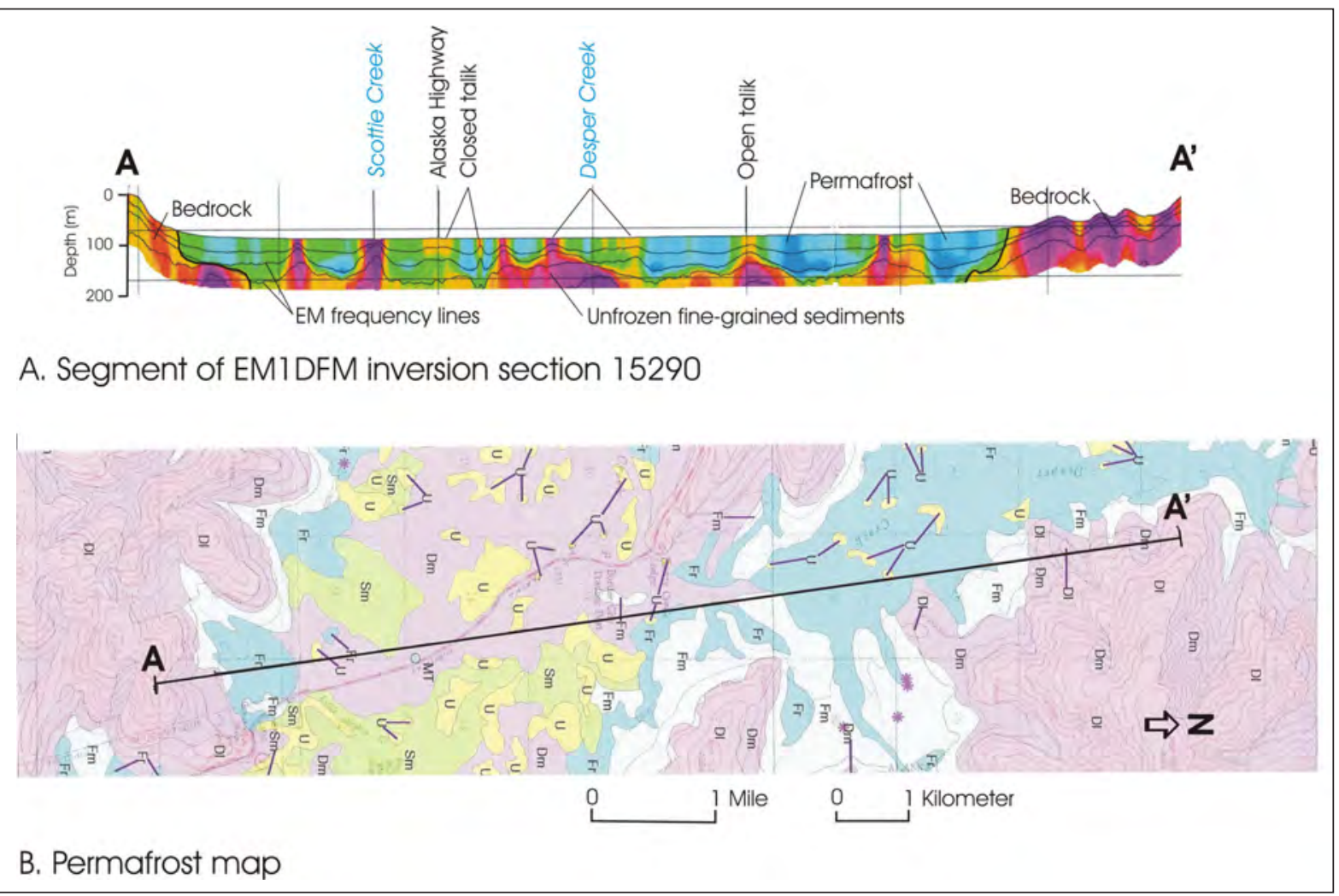

Figure 2. Segment of multilayer-inversion model (EM1DFM) 15290 (Burns and others, unpublished data) showing relations of permafrost to fine-grained valley fill in eastern Desper-Scottie creeks lowland (sheet 2). Permafrost in bedrock is unknown because resistivity was not evaluated. Symbols defined in sheets 1 and 2. 


\section{USE OF AIRBORNE-RESISTIVITY DATA}

W

ith the paucity of subsurface borehole data in the Alaska Highway corridor, airborne-resistivity data provide the best available (although indirect) measure against which our photo-interpreted permafrost mapping could be compared. Data for the airborne-resistivity sections were collected in the corridor in 2005 and 2006 (Solie and Burns, 2006, 2007).

For our comparison, we examined 31 of 74 resistivity sections that were generated by inducing electromagnetic currents into the ground from a transmitter in an instrument assembly suspended beneath a helicopter flown $\sim 30 \mathrm{~m}$ above the ground along transects spaced $0.4 \mathrm{~km}$ apart across the $320-\mathrm{km}$-long corridor. During the survey, five horizontal (coplanar) electromagnetic coils emitted primary magnetic fields at five frequencies between 140,000 and $400 \mathrm{~Hz}$, which penetrated the ground to different depths, depending on the frequency and the conductivity (inverse of the resistivity) of the ground (Sengpiel, 1988). In general, ground penetration was shallower at higher frequencies and deeper at lower frequencies. In the corridor survey, the $140,000 \mathrm{~Hz}$ signal generally penetrated to a depth of $\sim 5 \mathrm{~m}$ and sampled shallow sediments, and the $400 \mathrm{~Hz}$ signal typically sampled sediments as deep as $\sim 150 \mathrm{~m}$ (Solie and Burns, 2007). The response of the ground upon receiving the electromagnetic signals was to develop a secondary magnetic field, and signals emitted by that secondary field were captured by an antenna array in the suspended instrument package and recorded.

The resistivity of surficial deposits varies according to several factors, including the mineral composition, grain size, moisture content, and especially thermal state (Solie and Burns, 2006). After modeling the signals received from secondary magnetic fields produced in the corridor deposits, areas of different resistivity were plotted as different colors in sections developed by a multilayer inversion model (EM1DFM) (Burns and others, 2006) ${ }^{3}$, and the presence of frozen versus unfrozen sediments could be interpreted. During our comparison, we used EM1DFM inversion sections that show depths to which signals at $140 \mathrm{kHz}, 40 \mathrm{kHz}, 8.2 \mathrm{kHz}$, and $1.8 \mathrm{kHz}$ penetrated and portray the ground resistivity in colors ranging from dark blue (relatively high resistivity at $\sim 3,705$ $\mathrm{ohm}-\mathrm{m}$ ) where frozen to purple (relatively low resistivity at $\sim 232 \mathrm{ohm}-\mathrm{m}$ ) where unfrozen (fig. 2). On the basis of 11 gravimetric soil-moisture determinations in frozen eolian and reworked eolian sediments (Reger and others, in press), we anticipate that colors in the EM1DFM inversion sections reflect different ice contents: dark blue is inferred to contain moderate to high ice content ( 50 to $>1,000$ percent gravimetric soil moisture relative to dry weight), light blue is inferred to contain low to moderate ice content ( 25 to 50 percent gravimetric soil moisture), and light green is inferred to contain low ice content (6 to 25 percent gravimetric soil moisture).

One measure of the presence or absence of permafrost beneath the seasonally frozen active layer is the depth to which the induced electromagnetic energy penetrates. Shallower depths are sampled where the sediments are conductive (weakly resistant), like unfrozen, saturated, fine-grained deposits; greater depths are sampled where near-surface sediments are resistant (weakly conductive), like perennially frozen deposits with moderate to high ice content (Solie and Burns, 2007). One advantage of the EM1DFM inversion section is that the depths to which the various frequencies penetrated are displayed as lines superimposed over the resistivity colors (fig. 2). Where permafrost is present, frequency lines are deeper in the EM1DFM inversion section than where permafrost is absent.

Our EM1DFM inversion sections were printed at the scale of the permafrost map, on which the survey lines were printed, so that direct comparisons of permafrost boundaries were straightforward. During our comparisons, we recognized the need to consider possible influences of surficial and bedrock geology, hydrology, slope, and aspect. Basically, our initial mapping of permafrost in surficial deposits was much more reliable in the southern Yukon-Tanana Upland, indicating that changes to permafrost were minor there between 1978-1981, when the aerial photography was taken, and 2005-2006, when the electromagnetic survey was conducted. Interpretations of permafrost in bedrock are hampered by lack of knowledge of bedrock compositions and structures. In contrast, in the Northway-Tanacross Lowland many map boundaries had to be changed to reflect ground conditions indicated by the EM1DFM inversion sections, particularly along active drainages, where copious groundwater is present and taliks are more extensive than indicated by the 1978-1981 photography. Because of climatic warming, wildfires, and human alteration of the landscape since 1981 (Osterkamp and Romanovsky, 1999; Jorgenson and others, 2001), we believe that modern permafrost is slightly warmer, thinner, less extensive, and deeper than our maps portray.

${ }^{3} \mathrm{~A}$ total of 25 layers, each $4 \mathrm{~m}$ thick, was used to produce the inversion model (L.E. Burns, 09/22/2009 written communication). 
Although wildfires are considered to be the main agent for degradation of near-surface permafrost, the warming climate also exerts profound influences (Jorgenson and Osterkamp, 2005). Temperatures of discontinuous permafrost in central Alaska have increased by up to $1.5^{\circ} \mathrm{C}$ since the mid-1980s AD (Osterkamp and Romanovsky, 1999). Based on photo interpretation supplemented by numerous field observations, Jorgenson and others (2001) estimated that $\sim 42$ percent of the permafrost beneath the Tanana Flats south of Fairbanks is at least partially degraded. There, lowland fens are expanding at the expense of low-scrub lowlands and birch forests growing on slightly higher terrace surfaces. Permafrost degradation there is attributed in part to the flow of groundwater through fens, through taliks in the sporadic to discontinuous permafrost, and through underlying permeable coarse fluvial gravels (Racine and Walters, 1994; Jorgenson and others, 2001; Jorgenson and Racine, 2001). Measurements indicate that the groundwater temperature ranges from 2 to $5^{\circ} \mathrm{C}$. This reservoir of warmth helps thaw the fairly thin and warm $\left(0\right.$ to $\left.-3^{\circ} \mathrm{C}\right)$ permafrost.

\section{FACTORS AFFECTING DISTRIBUTION AND DISTURBANCE OF CORRIDOR PERMAFROST}

Permafrost distribution is a function of present and past climates (Hopkins and others, 1955). As a rough approximation, permafrost forms where the mean annual air temperature at standard instrument height is $<0^{\circ} \mathrm{C}$ (Péwé, 1982). To actually develop perennially frozen ground, the temperature of the ground surface must be $<0^{\circ} \mathrm{C}$ (Muller, 1947; Ferrians and others, 1969). The most accurate relation between permafrost extent and ground temperatures is reflected by ground temperatures measured in permafrost where there is no temperature variation (at and below the level of zero annual amplitude of Péwé, 1982) (fig. 3). In general, lowland permafrost is continuous (underlies $>90$ percent of the area) where the ground temperature at the depth of no annual temperature change varies from $-5^{\circ} \mathrm{C}$ to $-11^{\circ} \mathrm{C}$ for $>1 \mathrm{yr}$; permafrost is discontinuous (underlies 50-90 percent of the area) where steady ground temperatures are $-1{ }^{\circ} \mathrm{C}$ to $-5^{\circ} \mathrm{C}$ at the level of zero annual change; and permafrost is sporadic (underlies 10-50 percent of the area) or is composed of isolated small bodies ( $<10$ percent of the area) where unvarying ground

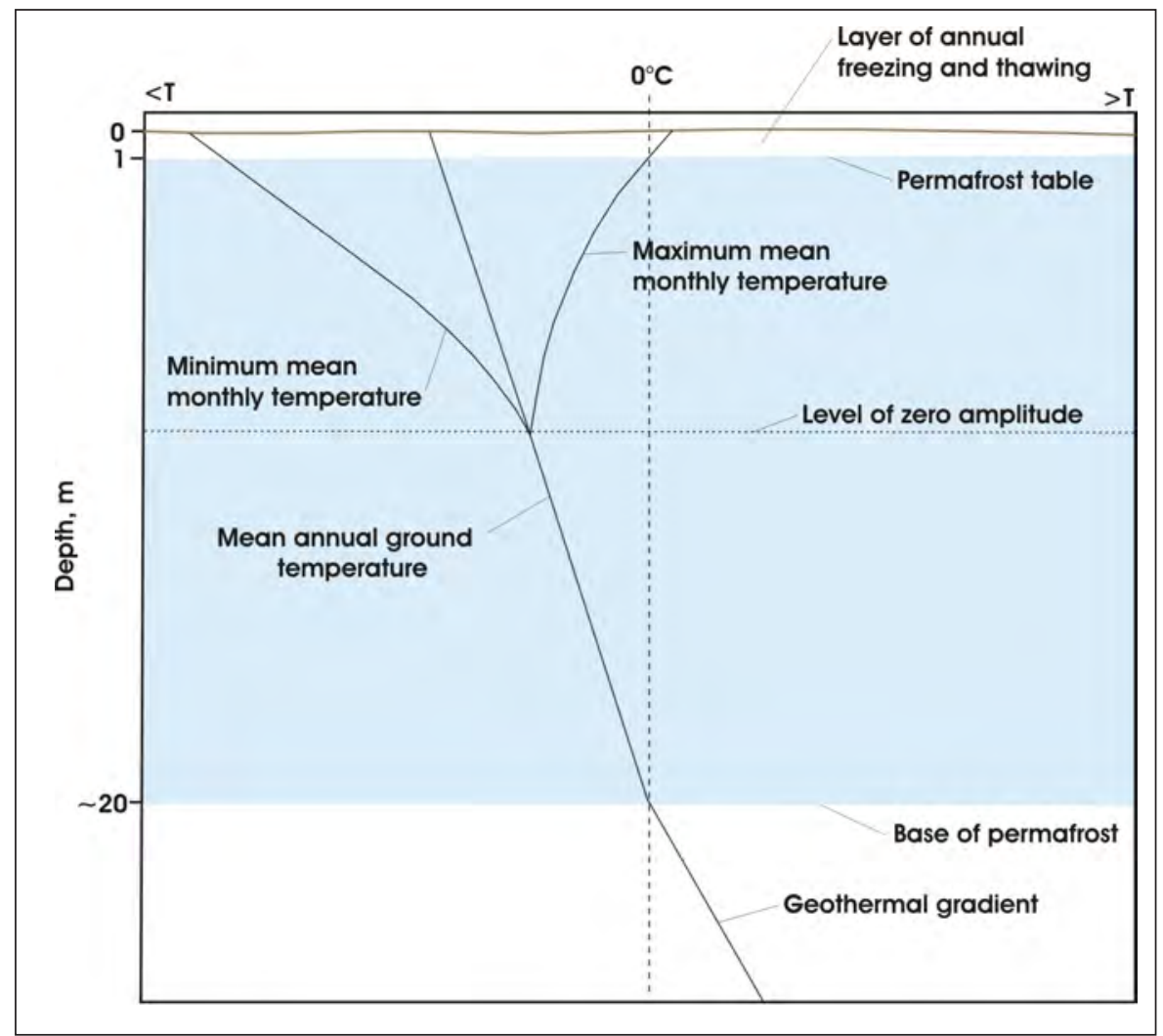

Figure 3. Generalized ground-temperature profile in area of permafrost (from Péwé, 1982, fig. 20). 
temperatures are $0^{\circ} \mathrm{C}$ to $1^{\circ} \mathrm{C}$ (Ferrians, 1965; Jorgenson and others, 2008). In complex mountainous terrains, differences in slope aspect, elevation, and snow characteristics produce highly variable permafrost temperatures.

Local variations in the depth, thickness, ice content, and temperature of permafrost are the result of differences in heat flow into and out of the ground, which are functions of the local geothermal gradient and interactions of climate and local physiographic and geologic conditions (Williams, 1970). For example, because of low sun angles at the northern latitude of the proposed corridor, the amount of solar radiation reaching the ground surface significantly affects the amount of heat potentially entering the ground. A $10^{\circ}$ south-facing slope receives $\sim 33$ percent more solar radiation than a $10^{\circ}$ north-facing slope and $\sim 14$ percent more solar radiation than a flat surface (Hinzman and others, 2006). Although mean annual air temperatures are generally only $\sim 3^{\circ} \mathrm{C}$ colder in valley bottoms and on north-facing slopes compared to south-facing slopes due to convective atmospheric mixing, ground temperatures are significantly colder on north-facing slopes and valley bottoms because (1) steep winter temperature inversions draw heat out of the ground, and (2) during summers there is significant insulation provided by the surface cover of mosses and lichens, which is widespread on north-facing slopes and valley bottoms. In summer, the moist groundcover dries in the continental climate and insulates permafrost from atmospheric temperature fluctuations, reducing heat flow from the warmer atmosphere into the colder ground. In winter, when this groundcover is frozen, heat flows from the warmer ground into the colder atmosphere. In wet sphagnum bogs, this natural heat pump allows 2.5 to 4.5 times more heat flow out of the ground in winter than heat flow into the ground in summer, promoting the formation and preservation of permafrost in these wetland sites (Kreig and Reger, 1982, pl. 5). Thus, topography and aspect significantly affect the distribution of permafrost and vegetation, which is a sensitive indicator of ground temperature conditions, especially in the southern Yukon-Tanana Upland.

Near-surface permafrost thaws when ground temperatures rise above $0^{\circ} \mathrm{C}$, as when the thermal properties of the ground surface are altered by human activities, geologic processes such as slope failures, or wildfires, so that heat flow into the ground exceeds winter heat loss. These changes lower the permafrost table and thicken the active layer of seasonal thawing (Ferrians and others, 1969; Jorgenson and Osterkamp, 2005; Lipovsky and others, 2006). Responses to the thawing of perennially frozen ground are functions of the amount and type of ground ice present, grain size, and the degree of disturbance. Permafrost contains several forms of ground ice, including buried snow, pond or lake ice, aufeis, glacier ice, pingo-ice lenses, foliated ice wedges, regelation and injection ice masses, small segregations of clear ice, and pore ice (French, 2007). Melting of massive ground-ice bodies typically results in considerable differential settlement of the ground surface and the formation of large thaw ponds, thaw lakes, and thaw basins (alases) (Kreig and Reger, 1982). Melting of foliated ice wedges, which form polygonal cells in permafrost, produces rounded mounds separated by differentially settled polygonal troughs (Péwé, 1954). Melting of permafrost rich in small, segregated ice lenses and thin ice seams produces general lowering of the ground surface without significant differential settling. Thawing of coarse sand and gravel with clear pore fillings can result in no settlement. Pre-burn vegetation typically returns a few years after a wildfire in an area, either directly or through a series of successional stages, depending on the type of vegetation formerly present and the severity of the burn (Chapin and others, 2006), and, with the return of surface vegetation, permafrost is generally re-established in soils thawed as a result of the wildfire.

\section{NORTHWAY-TANACROSS LOWLAND}

In the Northway-Tanacross Lowland southeast of Tok (fig. 1), permafrost is mapped as discontinuous with low to moderate ice content in mixed coniferous-deciduous forests on stabilized sand dunes on higher stream terraces (sheets 1 and 2). Discontinuous permafrost with low to moderate ice content is also mapped where the eolian cover sand is thin or lacking on older terraces and abandoned floodplains with extensive scrublands ${ }^{4}$. Sporadic permafrost is present in sediments of inactive and abandoned floodplains along active channels and in scrublands on low fluvial terraces, where surface water bodies are numerous, scattered, small, and shallow. According to Wallace (1948, p. 174), permafrost table is $\sim 0.3$ to $0.6 \mathrm{~m}$ deep beneath the moss-covered forest floor between thaw lakes.

Groundwater in $>75 \mathrm{~m}$ of alluvium at Northway airport is confined beneath permafrost as thick as $\sim 27 \mathrm{~m}$. Near the junction of the Northway spur and the Alaska Highway, two wells penetrated 45 and $49 \mathrm{~m}$ of permafrost (Williams, 1970, p. 33). Borings through stabilized sand dunes on a low terrace east of Northway airport penetrated $\sim 3 \mathrm{~m}$ of frozen ground. Several 15-m borings in the Nabesna River floodplain near Northway punched through permafrost (Wallace, 1948, p. 174), and perennially frozen ground is discontinuous beneath long-abandoned silt- and peat-filled

${ }^{4}$ Scrublands, which have open to closed canopies of low shrubs dominated by dwarf birch and ericaceous shrubs, include scattered black spruce and larch and are one of the most widespread taiga ecosystems in Alaska (Jorgenson and others, 2001). 
stream channels. However, examinations of EM1DRM inversion sections indicate that permafrost is absent beneath active stream channels and lakes and sporadic beneath recently abandoned, silt-filled channels. Peats are thawed in these channels and around the margins of larger lakes but are frozen and ice rich in smaller, isolated thaw basins and lowlands. Smaller thaw lakes typically occupy shallow, closed taliks ${ }^{5}$ underlain by permafrost.

Groundwater emergence is widespread in most of the distal Chisana River fan, and permafrost is mapped as sporadic to discontinuous with low to moderate ice content. Narrow riparian thickets of broadleaf trees and shrubs grow in the open taliks of active sloughs connecting clearwater lakes with turbid flows in the Chisana River and occupy more complex open taliks including large floodplain lakes along both banks of the Chisana River (sheet 2). Depths to permafrost in these taliks are inferred to be $>6 \mathrm{~m}$, particularly where numerous unfrozen ponds and lakes indicate widespread subsurface connections with copious quantities of groundwater in the distal part of the Chisana River fan. During high river stages, turbid river water enters the lowland lakes and builds deltas at the mouths of connecting sloughs.

An extensive shrub fen and examination of EM1DRM inversion section 14750 (Burns and others, unpublished data) indicate that the wetland between the Chisana River and the southern shore of Deadman Lake in the eastcentral Nabesna D-2 Quadrangle (sheet 2) receives large quantities of water from the Chisana River. Groundwater beneath this wetland flows from south to north through a former channel of the Chisana River that was blocked by sand dunes transported by winds blowing from the northwest to form the Deadman Lake basin. Groundwaters return to the Chisana River from Deadman Lake beneath the cover of eolian sand and through Tenmile Lake to the northwest. The presence of sporadic permafrost with low to moderate ice content is indicated by the numerous thaw ponds and thaw lakes in this wetland and by EM1DFM inversion sections 14720 and 14750 (Burns and others, unpublished data), which pass nearby.

Numerous thaw lakes are present on fine-grained, perennially frozen fluvial terraces in the Northway-Tanacross Lowland. These lakes typically exhibit circular to complex, locally scalloped shorelines, are 1.5 to $3 \mathrm{~m}$ deep, and have fairly flat bottoms (Wallace, 1948). Along actively retreating, steep lake banks, trees are characteristically tilted toward the lakes (fig. 4). Counts of growth rings in 15 tilted spruce trees indicate that banks recede 6 to 19 $\mathrm{cm} / \mathrm{yr}$ (Wallace, 1948, p. 179). Spruce trees with roots that subside beneath lake waters due to bank recession die after 10 to 15 years of root submersion. Where vegetation mats drooping down steep banks rip and expose the underlying ice-rich permafrost, accelerated melting locally produces mudflows and scalloped shorelines. Airborne-resistivity sections 14240, 14270, and 14300-301 (Burns and others, unpublished data) support the conclusion by Wallace (1948, p. 174) that permafrost is deeper than $3 \mathrm{~m}$ or does not exist beneath thaw lakes in the Northway-Tanacross Lowland.

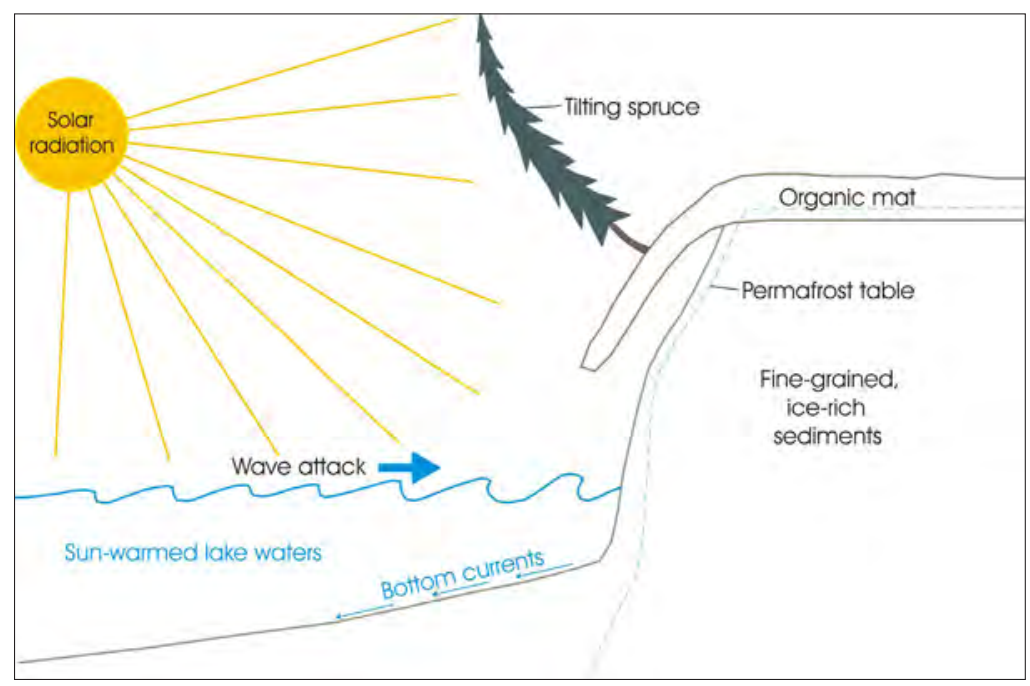

Figure 4. Factors influencing expansion of thaw lakes through bank recession.

\footnotetext{
${ }^{5}$ Taliks are unfrozen zones associated with permafrost, and several different taliks are recognized (French, 2007, table 5.4). For the purposes of this study, we use open taliks as unfrozen zones that penetrate through permafrost, and we use closed taliks as unfrozen zones beneath lakes and streams that do not penetrate through permafrost.
} 
Two models have been proposed for the evolution of thaw lakes in interior Alaska. Weber and Péwé $(1961,1970)$ and Péwé (1970) described changes in curvilinear scroll lakes in broad, meandering floodplains in the Yukon-Koyukuk Lowland (Reger and Hubbard, 2010a, fig. 3A). The series proposed by Wallace (1948) for the evolution of thaw lakes in the Nabesna-Chisana rivers area begins with a break in the vegetation mat over icerich permafrost, which initiates thawing that initially forms a small, generally circular basin in which water accumulates. Solar radiation warms this water, which has a fairly high specific heat (defined as calories of heat required to rise the temperature of 1 gm of water $1^{\circ} \mathrm{C}$ ), and secondarily thaws the surrounding frozen ground. Expanding thaw basins develop into thaw ponds and eventually into thaw lakes (fig. 5A). In the process, expanding lakes inevitably intersect and combine to form compound basins with scalloped shorelines inherited from initial circular shapes (fig. 5B). Scalloped shorelines also result from faster local thawing of ice-rich permafrost than in adjacent deposits with less ground ice. Through time, older groups of expanding thaw lakes combine to form extensive complexes, lake outlines become very irregular, and lakes commonly intersect stream channels (fig. 5C). During high stream stages, turbid floodwaters enter thaw-lake basins near active streams and deposit initially simple lake deltas that grow into complex forms by the extension and confinement of stream channels between natural levees. Complexes of levee-bound meandering stream channels eventually segment the lake basins into sub-basins (fig. 5D).

We recognize the circular-lake and early coalescent phases of Wallace's thaw-lake cycle on stream terraces isolated from active streams in the Northway Lowland and accept Wallace's explanation for their origin (figs. 5A and B). Study of EM1DFM inversion sections indicate that taliks are $~ 25-60$ m deep beneath these water bodies. However, we suggest a slightly different interpretation of Wallace's integrated-drainage and segmentedbasin phases (figs. 5C and D), which we note are invariably located close to active or former meandering channel systems. Because fluvial terraces, by definition, are not subject to seasonal flooding, thaw lakes on terraces distant from active or formerly active streams cannot develop flood-related deltas and integrated drainages. In our model, large and complex lake basins (figs. 5C and D) evolve by thermokarst modification of ice-rich bank sediments of lakes in slackwater basins associated with meandering streams and do not necessarily originate as local thaw basins and ponds. Actively caving, scalloped lake banks and tilted shoreline trees demonstrate that lakes in slackwater basins are modified by thermoerosion of ice-rich permafrost; and remnants of former natural levee-lake delta complexes demonstrate that these features are fine grained and are also subject to thermokarst degradation (fig. 6). Thus, meandering, levee-confined channels

Figure 5. Evolution of thaw lakes in Nabesna-Chisana rivers area, Northway lowland, according to Wallace (1948, figs. 4-7).

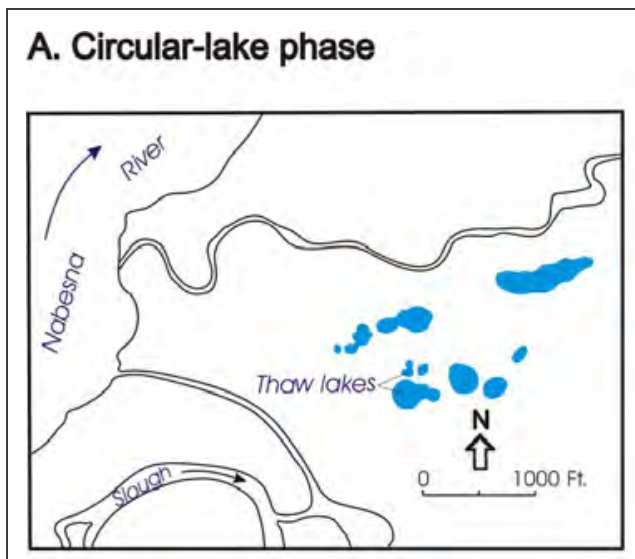

\section{B. Early coalescent phase}

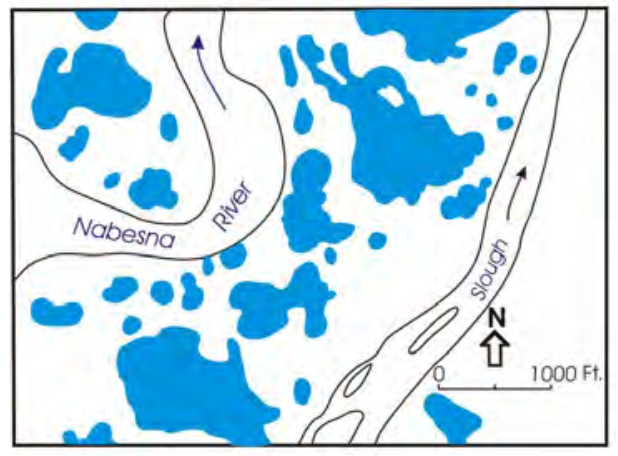

\section{Integrated-drainage phase}

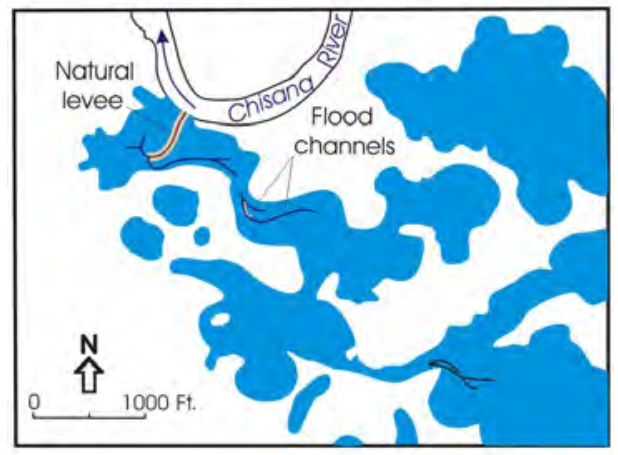

\section{Segmented-lake phase}

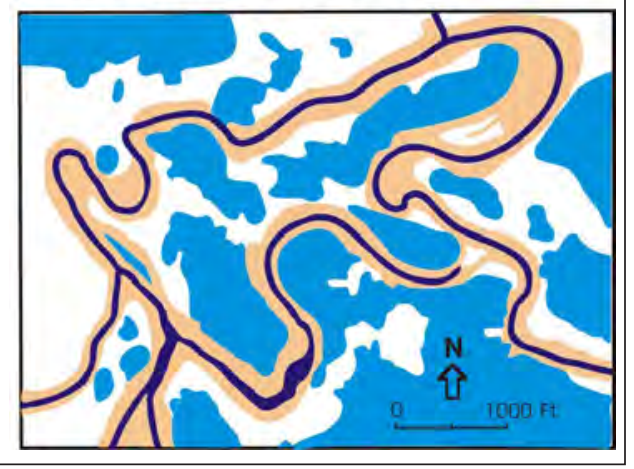


and complex lake deltas that fill and segment slackwater-basin lakes are a natural consequence of long-term river flooding and are not necessarily related only to thaw-lake development.

Scattered thaw-lake basins drain suddenly when headward-eroding tributaries intersect their margins, initially exposing former fine-grained lake-bottom sediments. Depending on the topography in these former lake basins, subsequent basin deposits can include complexes of pond or lake sediments in depressions, mass-movement deposits near steep former lake margins, peat that develops on higher ground, and eolian sediments (Murton, 1996).

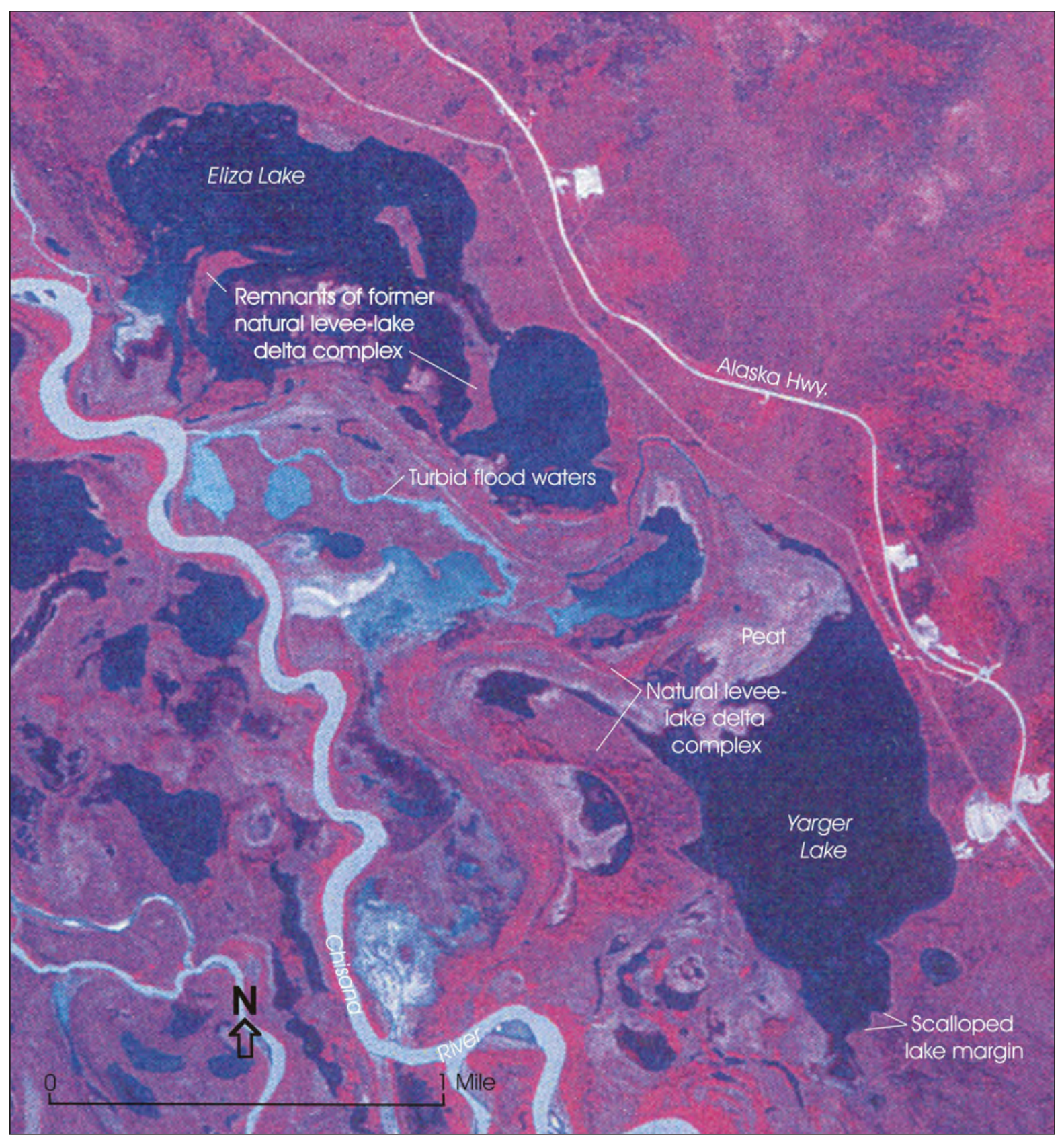

Figure 6. Vertical false-color infrared aerial photograph showing natural levee-lake delta complexes that intricately divide former large slackwater lake basin into numerous subbasins, including Eliza and Yarger lakes, in northeastern Nabesna D-2 Quadrangle. Note contrast between turbid river waters and clear lake waters. Scalloped shorelines and remnants of former natural levee-delta systems are evidence of thermokarst degradation (Alaska High Altitude Photograph ALK 60 CIR 21-408 taken July 1978). 
Permafrost soon becomes re-established in former lake basins, where local relief develops due to the growth of ground ice in the aggrading permafrost. Because of slumping of older bank sediments into thaw lakes and their subsequent redistribution throughout the basin by waves and currents, radiocarbon ages of thaw-lake deposits are generally considered to be unreliable (Nelson and others, 1988; Abbott and Stafford, 1996).

\section{SOUTHERN YUKON-TANANA UPLAND}

The presence of permafrost in surficial deposits beneath lower slopes and lowlands in the southern YukonTanana Upland is demonstrated by numerous open-system pingos, thaw ponds and thaw-lakes, and networks of polygonal ground, as well as thermokarst gullies and debris flows that developed as a consequence of widespread recent wildfires. A survey of EM1DFM inversion sections across the southern upland indicates that permafrost is continuous with moderate to high ice content in thick valley fills. Perennially frozen ground is apparently discontinuous with low to moderate ice content in thin fills in upper drainages, although we have not evaluated possible influences of the resistivity of near-surface bedrock on electromagnetic responses where unconsolidated surficial deposits are thin. Many small tributary drainages head in thaw ponds and thaw lakes, peat bogs, and open-system pingos, hinting of at least limited groundwater access. Surface vegetation in wetlands underlain by shallow, continuous permafrost consists primarily of sedge tussocks, low willow and resin-birch shrubs, and scattered stunted black spruce (fig. 7). Infiltration of precipitation waters is restricted by the shallow permafrost, causing shallow surface water to pond between sedge tussocks and locally around stunted black spruce. In these areas ground ice is present as small segregations, polygonal ice wedges, and lenses of pingo ice. Although there is a general lack of thermokarst features, study of EM1DFM inversion sections indicates that the thick, featureless blanket of undifferentiated eolian deposits in local basins in the southern Yukon-Tanana Upland is discontinuously frozen with low to moderate ice content.

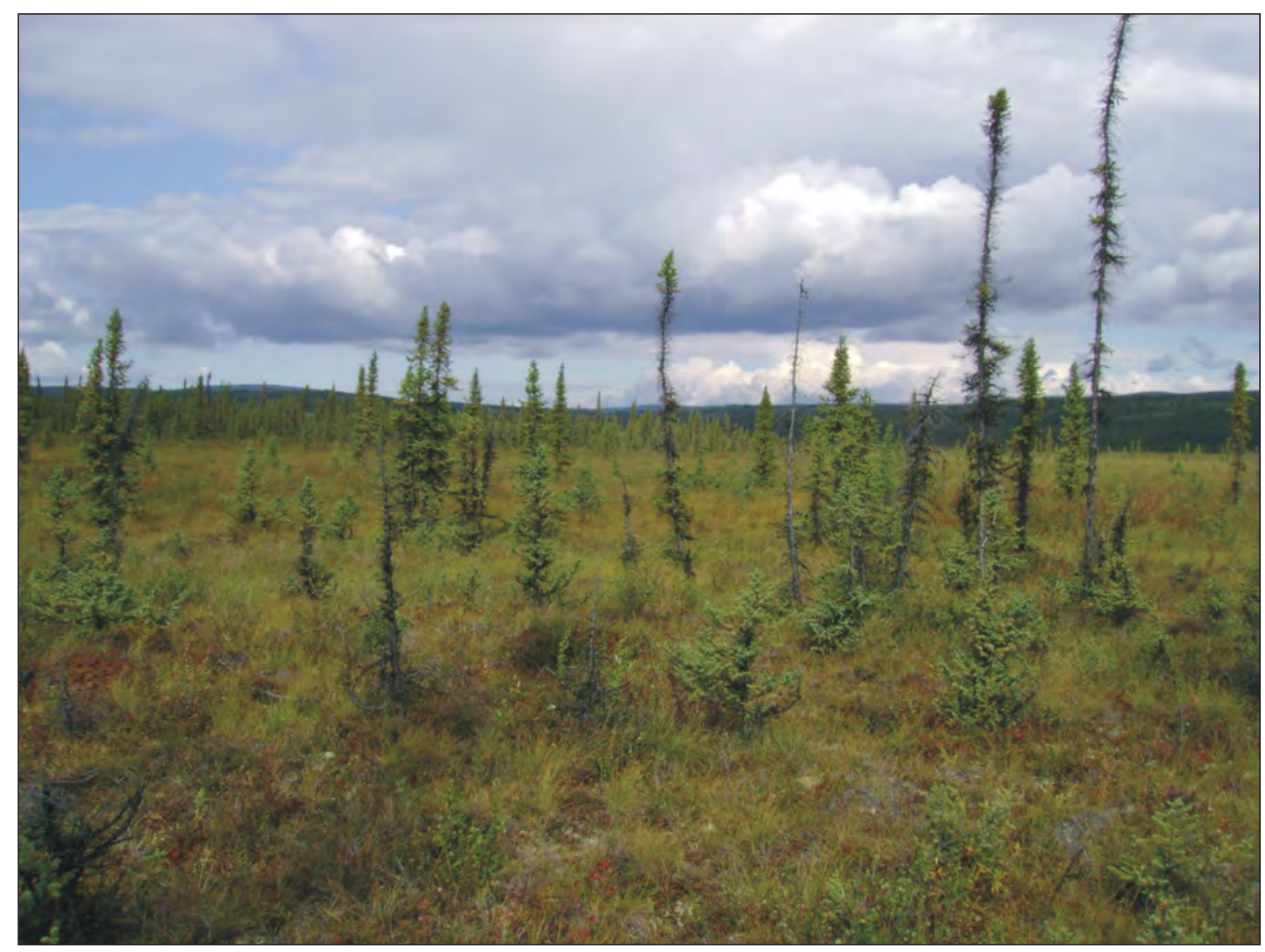

Figure 7. Typical sedge tussock and scattered black spruce vegetation on shallow continuous permafrost, floor of upper Ladue River valley, southern Tanacross B-3 Quadrangle. Depth to permafrost is $33 \mathrm{~cm}$. Photograph taken 08/18/2009 by T.D. Hubbard. 
Damundtali Lake is one of five small lakes that occupy depressions in an irregular, 1.6 by $1.1 \mathrm{~km}$, sedimentfilled basin at the head of a drainage on the northeastern flank of Cheneathda Hill in the southeastern Tanacross A-2 Quadrangle (sheet 1). Examination of EM1DFM inversion section 14690 (Burns and others, unpublished data) indicates that permafrost in this local basin is discontinuous and has a maximum thickness $>100 \mathrm{~m}$. Closed taliks beneath the small lakes in this basin are $\sim 30 \mathrm{~m}$ deep.

The densest concentrations of open-system pingos in corridor segment 3 are present in continuously and discontinuously frozen valley fills of the Ladue River drainage in the southern Tanacross B-3 Quadrangle (fig. 8) and in small valleys in the northwestern Nabesna D-1 Quadrangle (sheets 1 and 2), where they have evolved a morphological series from small ice-cored mounds through obvious small knobs supporting robust trees of the boreal forest to circular ponds and lakes (see sidebar).

The route of the Alaska Highway through the southern Yukon-Tanana Upland crosses several kilometers of ice-rich permafrost. Periodic road maintenance, including reroutes, emplacement of fills, repaving, and special designs to stabilize thick fills, has been required in the past and will be required in the future to accommodate this geologic hazard.

Two large retrogressive landslides are expanding headward toward the Alaska Highway from southwest-facing bluffs of the Chisana River by the thawing of frozen retransported loess and eolian sand near Alaska Highway mileposts 1265 and 1267 in the southwestern Tanacross A-2 Quadrangle (Reger and others, in press, sheet 1$)^{6}$. The large failure near milepost 1267 seriously affected the Alaska Highway and in 2004 required moving the highway northward away from the Chisana River floodplain (Frank Ganley, 08/10/2009 written communication) (fig. 10). Features produced by active displacements in the landslide include: (1) active, linear to arcuate scarps in the body of the slide in the

\section{EVOLUTION OF OPEN-SYSTEM PINGOS}

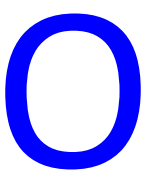
pen-system pingos develop in permafrost where a suitable subsurface plumbing system exists, including extensive uplands where precipitation and runoff waters can enter the groundwater system, gentle to moderate slopes to establish hydraulic gradients, intrapermafrost or subpermafrost drainageways through taliks, and local areas of groundwater emergence (Holmes and others, 1968; Ferrians, 1988; French, 2007). A subsurface ice lens, which is the core of a pingo, initially forms at a fairly shallow depth in permafrost where groundwater under artesian pressure is prevented from reaching the ground surface by frozen ground. Hydrostatic stresses and growth of the ice lens initially dome the ground surface to form a low mound, and the surface vegetation is unaffected by significant drainage changes (fig. 9A). During the next several decades to centuries, lens growth continues, and pingo relief increases to form a small hill (fig. 9B). In the process, small concentric and radial cracks develop in the seasonally thawed sediments above the expanding ice lens in the summit of the pingo, and vegetation adapts to better soil drainage and deepening permafrost. Ultimately, summit cracks widen enough that the ice core is exposed to atmospheric temperature variations, and the top of the ice core begins to melt at the summit each summer, initially forming a shallow depression. At this stage, maximum relief has been achieved and growth ceases. The shallow summit depression gradually deepens and expands to form a summit crater through slumping of concentric blocks (fig. 9C). Numerous springs in the floor of the crater feed cold water into the crater, and a shallow summit pond develops. Warming of this small water body by solar radiation accelerates melting of the underlying ice core. A mature boreal forest survives on the pingo, typically in marked contrast to the sedge tussocks, shrubs of resin birch and willows, and scattered, stunted black spruce trees in the scrublands surrounding the pingo, where permafrost is shallow. Eventually, after several more decades to centuries, the expanding pond breaches its confining walls and is the source of a surface drainage network (fig. 9D). During succeeding decades and centuries, the ice core gradually disappears. Concurrently, the crater walls decrease in height, and eventually only isolated low remnants of the former crater rim remain. Remnants of the clump of trees that formerly existed on the pingo hill survive on these stable mounds (fig. 9E). Typically, a shallow, spring-fed circular pond persists where the ice core formerly existed and is gradually filled by peat in marshes that encroach from the upslope side and gradually become perennially frozen. Dating of sediments in Interior pingos demonstrates that they all evolved during the Holocene (Holmes and others, 1968).

\footnotetext{
${ }^{6} \mathrm{~A}$ much smaller slope failure of this type is located $0.6 \mathrm{~km}$ southeast of Steve Lake along the margin of the Chisana River floodplain in the north-central Nabesna D-2 Quadrangle (Reger and Hubbard, in press, sheet 2)
} 


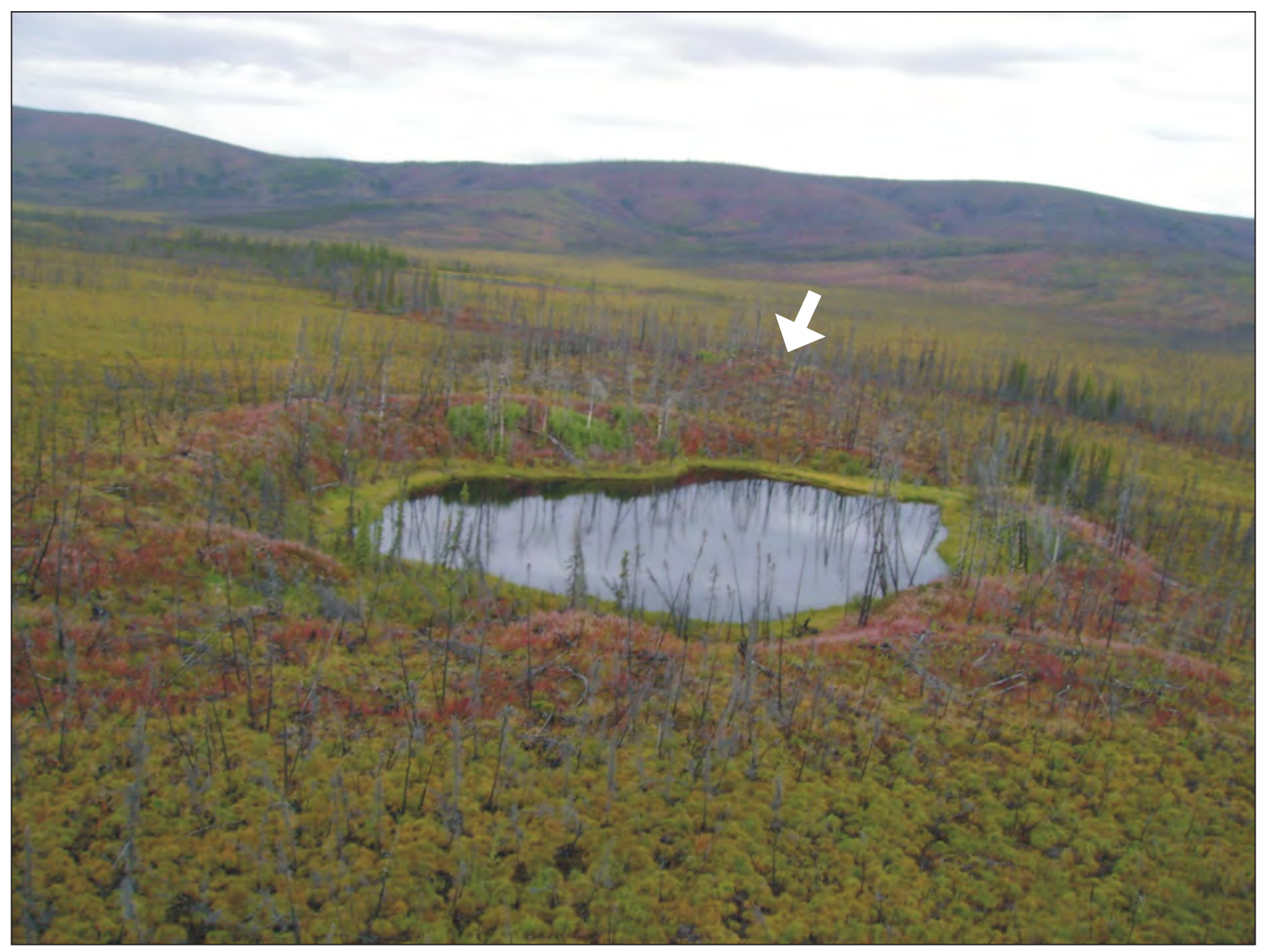

Figure 8. Pair of open-system pingos on perennially frozen lower southern slope of upper Ladue River valley in southern Tanacross B-3 Quadrangle. High relief of rear pingo (arrow) indicates ice core is intact. Pingo in middleground has collapsed, and coldwater springs feed crater pond, which drains through breach in remnant pingo rim. Sedge tussocks dominate foreground. Photograph taken 08/19/2009 by T.D. Hubbard.

former roadbed (figs. 11A and B); (2) tilting of live spruce trees toward the head of the slide (fig. 11C); (3) splitting of live spruce trees across spreading tension cracks (fig. 11D); and (4) advance of the landslide toe against marginal vegetation (fig.11E). This failure and similar slope failures were probably initiated by stream erosion along the margin of the Chisana River floodplain and are dominated by complex slumping of blocks of thawing perennially frozen silt. Cracks developed in pavement emplaced in the summer of 2008 and in adjacent fill along the southwestern side of the Alaska Highway near milepost 1267 demonstrate continuing northward expansion of the retrogressive failure.

\section{GARDINER CREEK LOWLAND}

Examination of EM1DFM inversion sections across the Gardiner Creek lowland indicates that permafrost is continuous, has a maximum thickness $>100 \mathrm{~m}$, and ice content ranges from low to high percentages (sheet 2). The riparian vegetation of tall spruce trees and large willow shrubs on low terraces adjacent to lower Gardiner Creek indicates the presence of a 290 - to 400-m-wide talik along that stream. Examination of EM1DFM inversion sections 14830 and 14840 (Burns and others, unpublished data) indicates that the thawed zone penetrates through the thick continuous permafrost in the Gardiner Creek lowland (open talik).

Several collapsed open-system pingos are identified in the extensive frozen sand dunes in the Gardiner Creek lowland, many related to former local drainages now filled with fine-grained, organic, retransported eolian sediments mixed with lowland loess. These deposits are mapped as continuously frozen with moderate to high ice content (sheet 2). Differentiating uncollapsed pingos from small sand dunes is not practical using aerial photographs, 


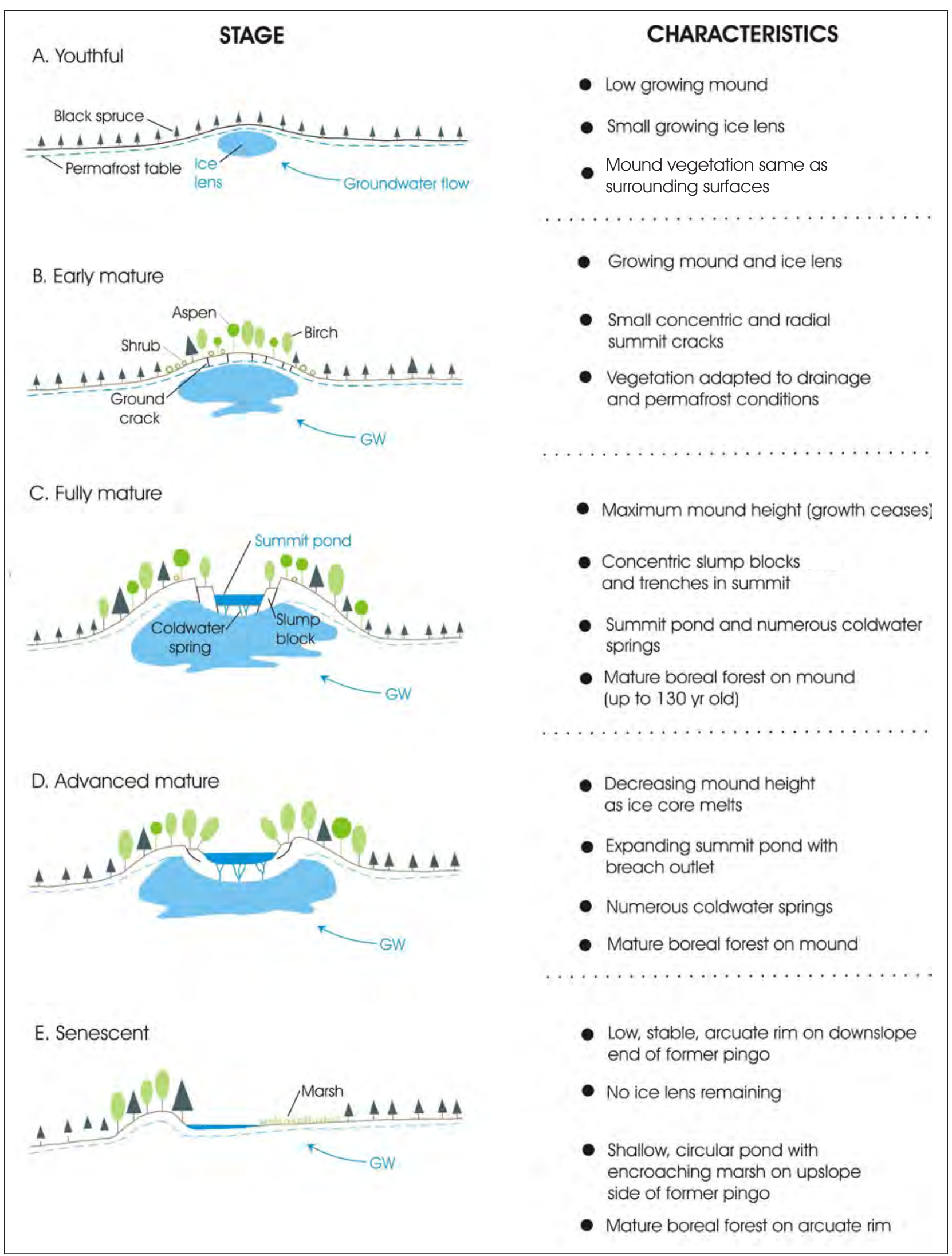

Figure 9. Evolution of open-system pingos (developed from Holmes and others, 1968). 


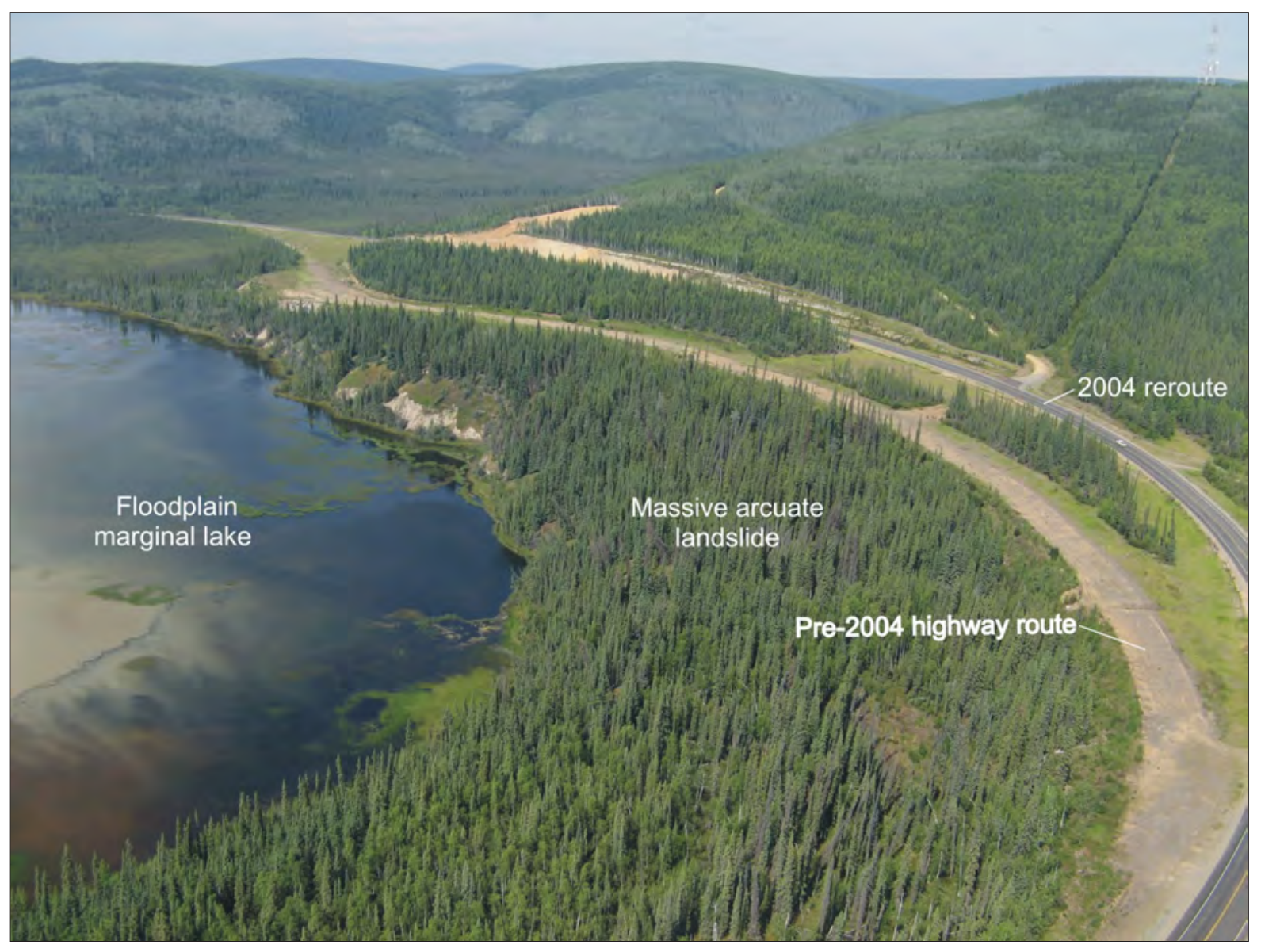

Figure 10. Aerial view toward northwest of large, arcuate, retrogressive failure that intersected Alaska Highway near milepost 1267 and required rerouting in 2004. Photograph taken 07/31/2009 by R.A. Combellick.

and some open-system pingos probably remain unmapped. Similarly, some features we map as thaw lakes in the Gardiner Creek lowland could be the remains of degraded open-system pingos or vice versa.

Several test pits excavated into frozen sand dunes in the Gardiner Creek lowland exposed fine to medium sand with up to a trace of silt beneath 15 to $30 \mathrm{~cm}$ of silty loess. Depths to permafrost ranged from 45 to $68 \mathrm{~cm}$, and little visible ice was observed. Laboratory analyses indicate that gravimetric soil moisture in frozen eolian sand ranges from 17 to 45 percent ( $n=5$ ) (table 1, samples M-4 to M-6, M-8, and M-9; sheet 2) ${ }^{7}$. Thawed samples were thixotropic where silty.

In the central Nabesna D-1 Quadrangle ( sheet 2, locality GC), an extensive wetland with numerous thaw lakes and ponds occupies a probable former lake basin that likely drained eastward into a north-flowing branch of Gardiner Creek. Present drainage from the basin is northward past a collapsed open-system pingo into lower Gardiner Creek. Surface vegetation and examination of EM1DFM inversion section 15080 (Burns and others, unpublished data), which passes through the eastern margin of the basin, indicate that the basin contains discontinuous permafrost.

Near Alaska Highway milepost 1240 (sheet 2, locality PES ), a thick roadfill crosses a small valley containing perennially frozen, ice-rich, retransported eolian sand. The mean annual air temperature at the site is estimated to be $5.7^{\circ} \mathrm{C}$ (Braley and others, 1991). During the spring of 1983, the Research Section of the Alaska Department of Transportation and Public Facilities (Fairbanks) installed and subsequently tested the efficiency of an experimental open-duct structure in the thick fill (see sidebar, p. 17) (sheet 2).

${ }^{7}$ Elsewhere in segment 3, samples of frozen silt-rich loess collected from two test pits contained 21 and 39 percent gravimetric soil moisture (table 1, samples M-1 and M-3; sheet 2), and depths to permafrost at those sites were 25 to $55 \mathrm{~cm}$. Although no visible ice was observed in the frozen loess, thawed silty loess was thixotropic. Analyses of four moisture samples in complex reworked and lowland loess demonstrated that gravimetric soil moisture varies from 33 to 345 percent (table 1, samples M-2, M-7, M-10 and M-11; sheets 1 and 2). Depths to permafrost in those test pits were 34 to $60 \mathrm{~cm}$. Although these soils were thixotropic when thawed, ground ice was visible as scattered, clear crystals $\leq 3 \mathrm{~mm}$ in diameter only in sample M-2. 


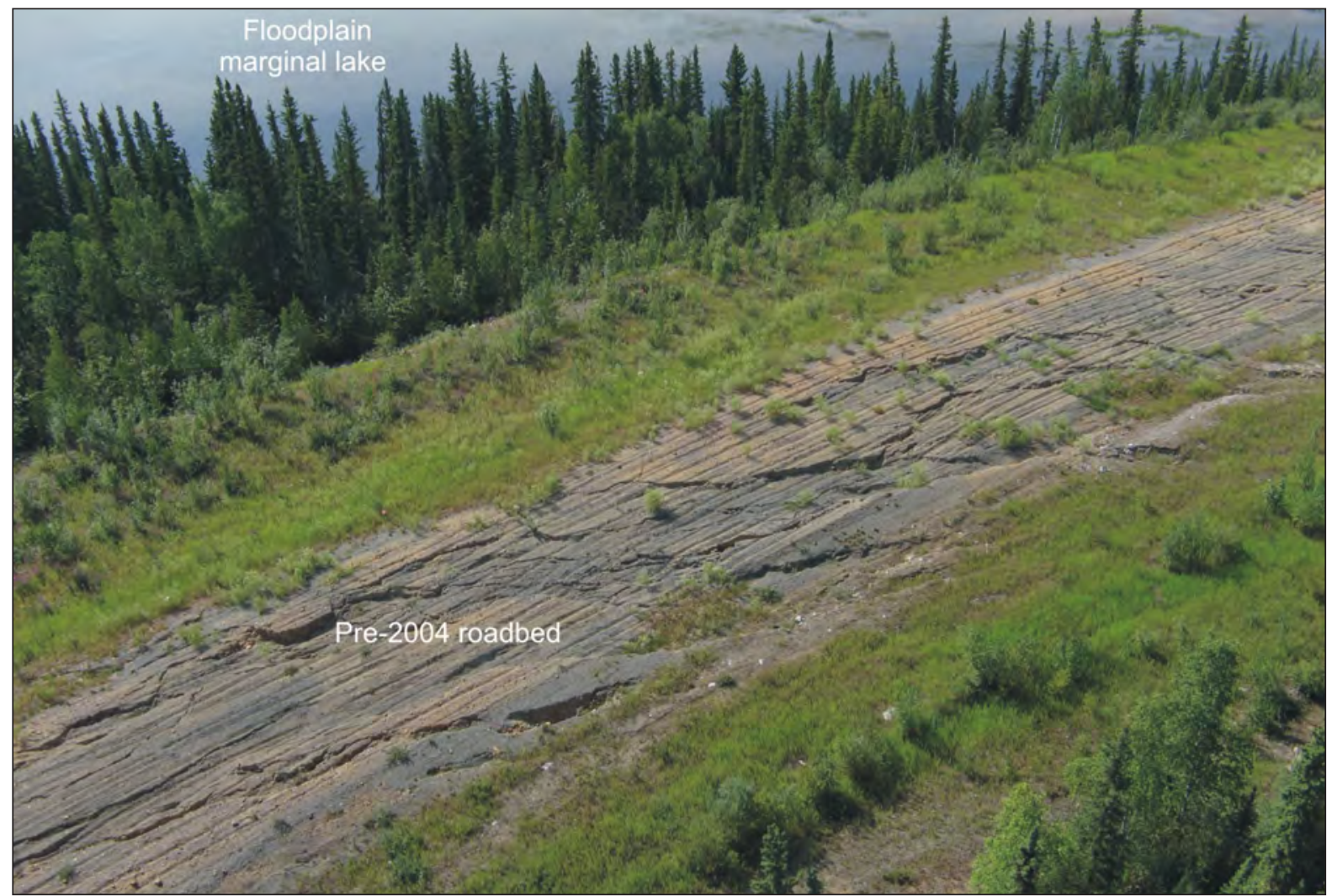

Figure 11A. Aerial view toward southwest of complex linear and arcuate ground cracks and scarps produced by active landsliding in former roadbed of Alaska Highway near milepost 1267. Photograph taken 07/31/2009 by R.A. Combellick.

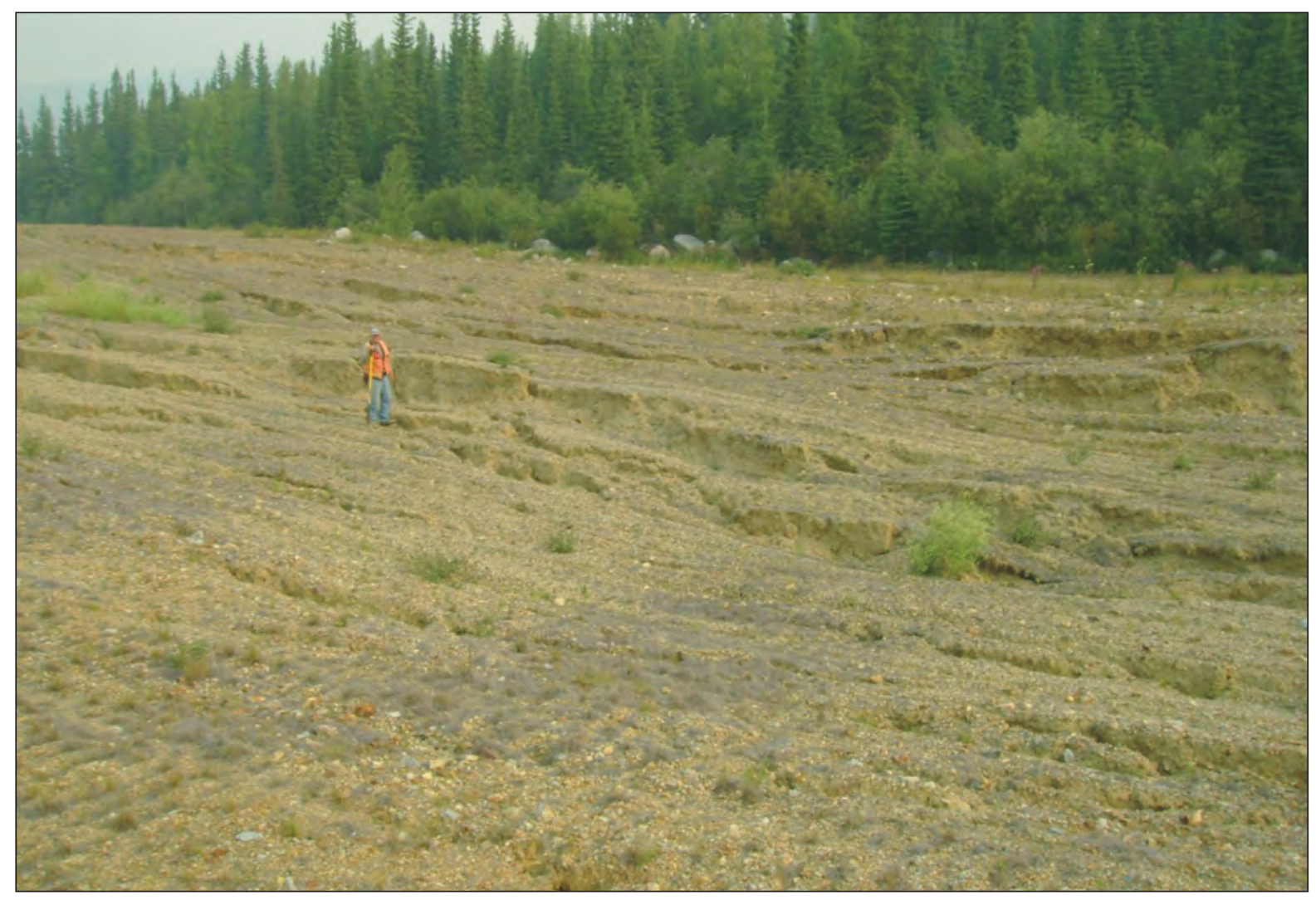

Figure 11B. Active landslide scarps offset abandoned roadbed of Alaska Highway near milepost 1267. Person provides scale. Photograph taken 08/01/2009 by T.D. Hubbard. 


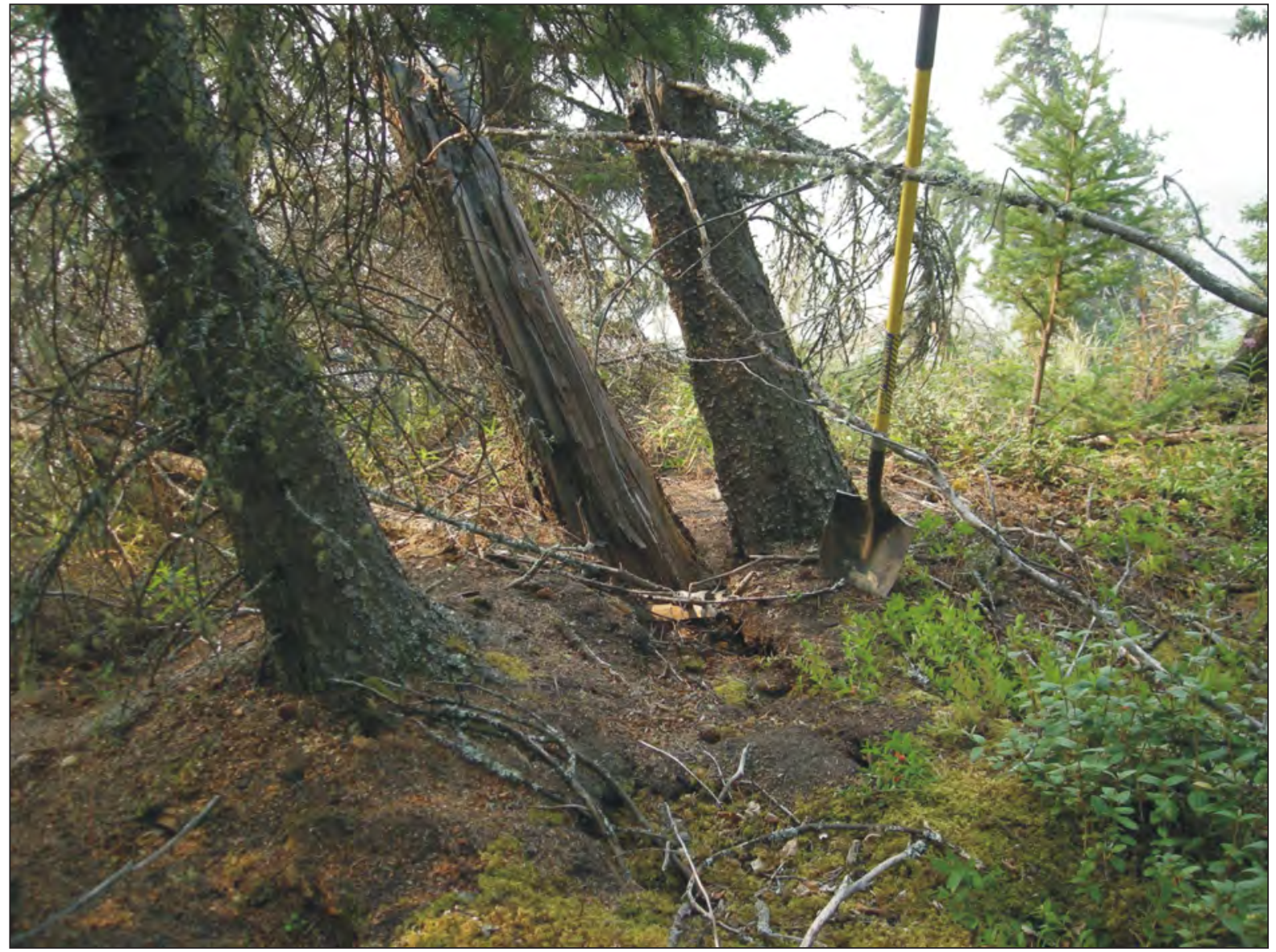

Figure 11C (above). Live spruce trees tilted toward head of active landslide in thawing retransported silt near Alaska Highway milepost 1267. Yellow shovel handle $1 \mathrm{~m}$ long. Photograph taken 08/01/2009 by R.D. Reger.

Figure 11D (right). Live spruce tree split by widening tension crack in active landslide in thawing retransported silt near Alaska Highway milepost 1267. Yellow shovel handle $1 \mathrm{~m}$ long. Photograph taken 08/01/2009 by R.D. Reger.

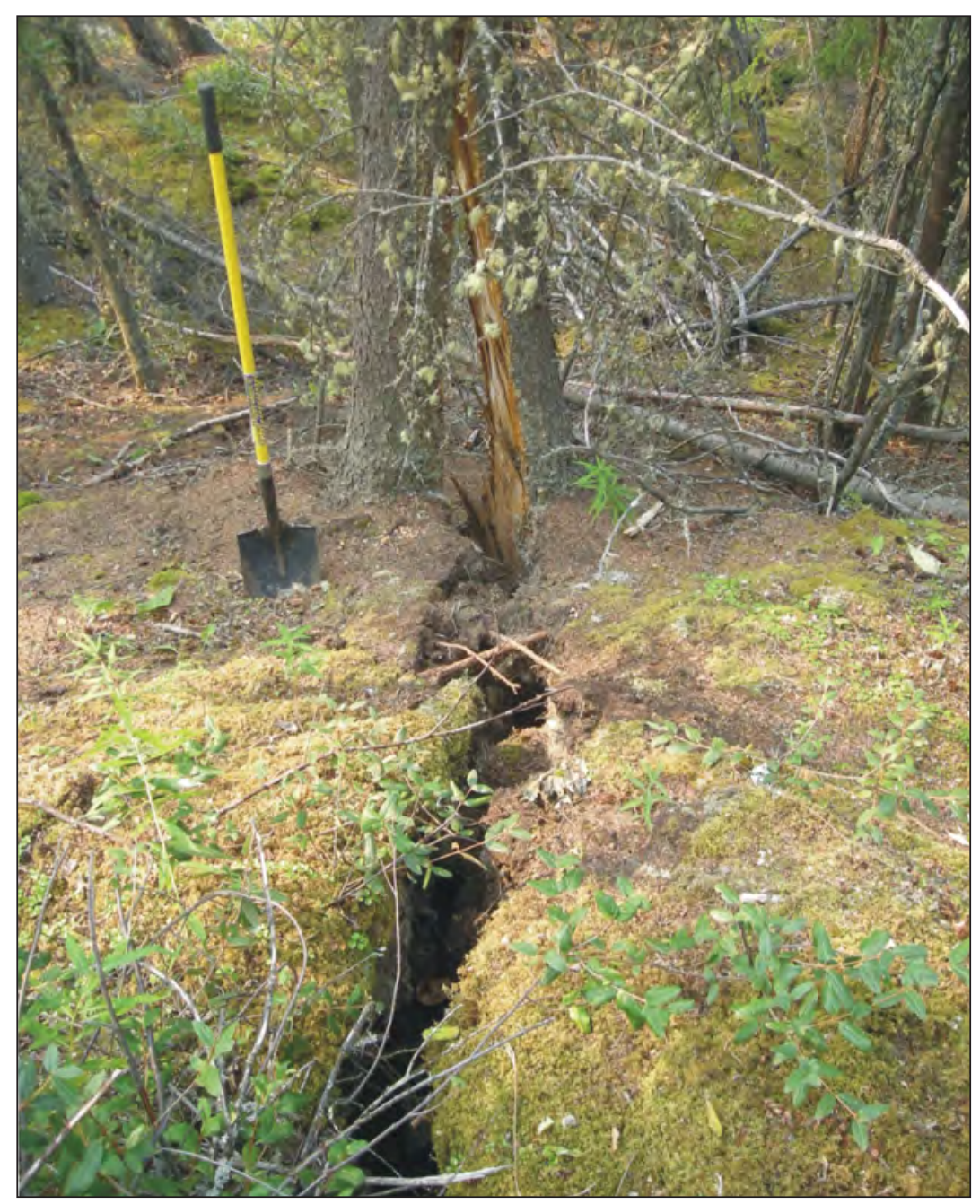




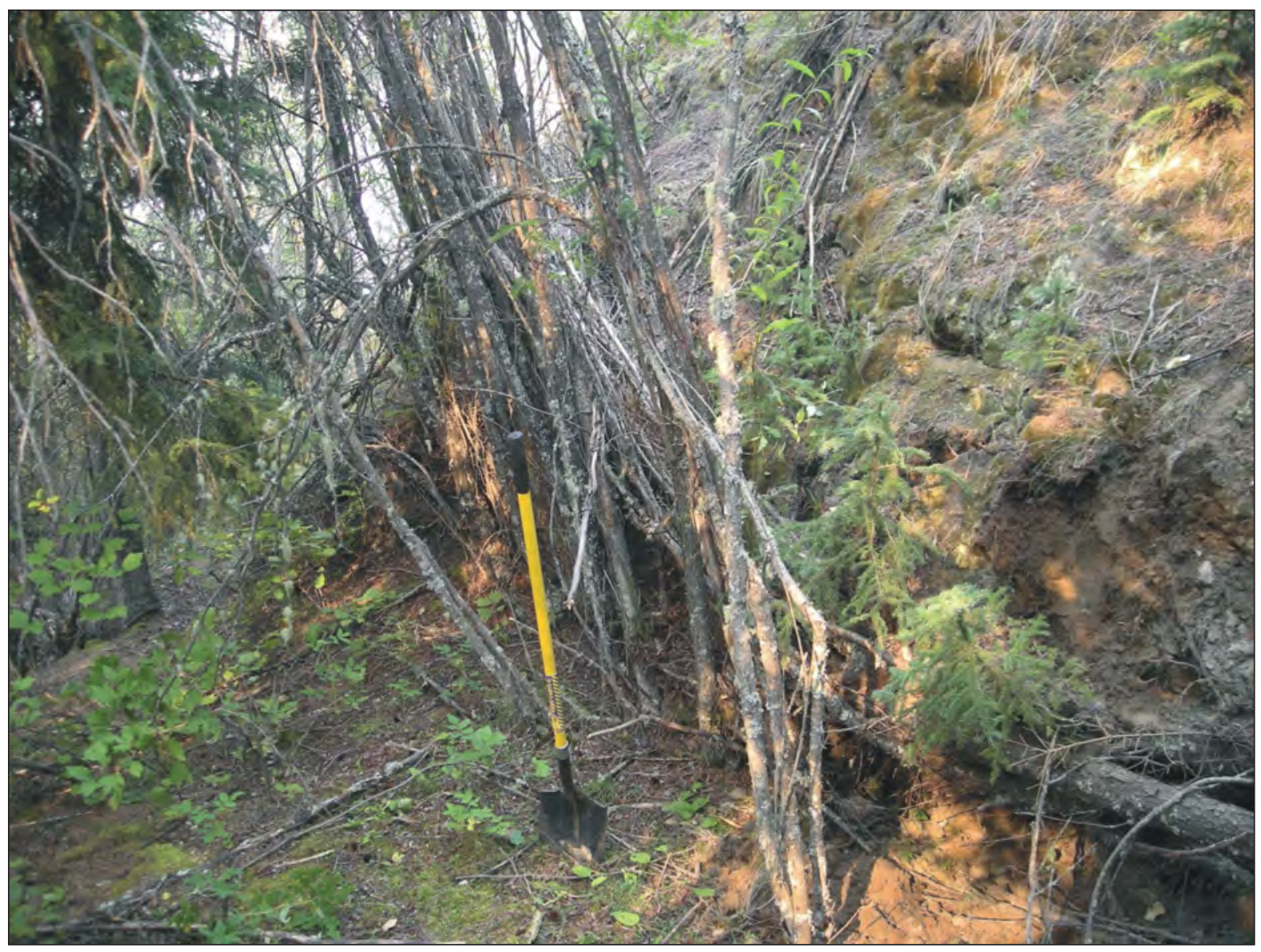

Figure 11E. Tilting and compression of willow shrubs by advance of active landslide in thawing retransported silt near Alaska Highway milepost 1267. Yellow shovel handle $1 \mathrm{~m}$ long. Photograph taken 08/01/2009 by R.D. Reger.

Table 1. Gravimetric soil moisture content of samples of eolian and retransported eolian deposits in pipeline corridor segment 3, Tanacross and Nabesna quadrangles.

\begin{tabular}{|c|c|c|c|}
\hline \multirow[b]{2}{*}{$\begin{array}{l}\text { Sample } \\
\text { number }^{\mathrm{a}}\end{array}$} & \multirow[b]{2}{*}{ Composition } & \multicolumn{2}{|c|}{$\begin{array}{l}\text { Gravimetric soil moisture content } \\
\text { (percent dry weight) }\end{array}$} \\
\hline & & Eolian sand & $\begin{array}{l}\text { Lowland and } \\
\text { retransported } \\
\text { loess }\end{array}$ \\
\hline M-1 & $\begin{array}{l}\text { Frozen eolian sand, well bonded, no visible ice; thawed, wet silty loess, } \\
\text { thixotropic }\end{array}$ & 45 & 21 \\
\hline$M-2$ & $\begin{array}{l}\text { Frozen, well bonded, black peaty and woody retransported organic silt, } \\
\text { scattered clear ice crystals } \leq 3 \mathrm{~mm} \text { across }\end{array}$ & --- & 345 \\
\hline $\mathrm{M}-3$ & Frozen, well bonded silty loess, no visible ice, thixotropic when thawed & --- & 39 \\
\hline $\mathrm{M}-4$ & $\begin{array}{l}\text { Frozen, well bonded, fine to medium eolian sand with trace silt, } \\
\text { thixotropic when thawed }\end{array}$ & 28 & --- \\
\hline M-5 & Frozen, well bonded, fine to medium eolian sand, no visible ice & 19 & --- \\
\hline$M-6$ & $\begin{array}{l}\text { Frozen, moderately bonded, medium eolian sand with trace silt, no visible } \\
\text { ice }\end{array}$ & 19 & --- \\
\hline $\mathrm{M}-7$ & Frozen, well bonded, retransported organic silt, no visible ice & ---- & 76 \\
\hline $\mathrm{M}-8$ & $\begin{array}{l}\text { Frozen, moderately bonded, clean, fine to medium eolian sand, no visible } \\
\text { ice }\end{array}$ & 17 & --- \\
\hline M-9 & $\begin{array}{l}\text { Frozen, well bonded, medium eolian sand, no visible ice, thixotropic when } \\
\text { thawed }\end{array}$ & 25 & --- \\
\hline M-10 & $\begin{array}{l}\text { Frozen, well bonded, retransported organic fine sand with some silt, no } \\
\text { visible ice }\end{array}$ & --- & 60 \\
\hline $\mathrm{M}-11$ & Frozen, well bonded retransported silt, no visible ice & --- & 33 \\
\hline
\end{tabular}

aSample locations shown on sheets 1 and 2. Samples M-1-M-9 collected 07/20/2009. Samples M-10 and M-11 collected 08/01/2009. 


\section{MILEPOST 1240 FILL-CHILLING EXPERIMENT}

T he experimental open-duct structure was intended to chill and stabilize the thick highway fill and preserve the underlying permafrost. The ducting is composed of $0.6-\mathrm{m}$-diameter, galvanized, corrugated culverts. Five 35.2-m-long sections placed horizontally parallel to the highway centerline near the northern and southern margins of the fill comprise the main (central) components of two culvert sets in the structure (Braley and others, 1991). At one end of each long culvert section and perpendicular to it is a near-horizontal, 9.7-m-long culvert section that is attached to a 1.2-m-long section of culvert that slopes upward $45^{\circ}$ and sticks above the embankment surface far enough to be above local snow levels (Esch, 1988) (fig. 12). This short, inclined section of culvert introduced cold ambient air through the intervening culvert to the central culvert. Adjustable metal covers on the intake ends of the sloping sections exposed to the atmosphere were designed to be opened in winters and closed in summers (when warm winds could detrimentally cause warming of the highway fill) (fig. 13). At the other end of each long central culvert section is a vertical, 3.7-m-long exhaust stack that extends from the buried culvert to slightly above the embankment slope and is open to the atmosphere beneath a metal cone (rain cap) that prevents precipitation from entering the stack (figs. 12 and 13).

The open-duct structure is designed to passively chill the thick highway fill by convection when cold winter air enters the exposed and open culvert ends at the edges of the fill, and is warmed by the ground enclosing the buried culverts (Zarling and others, 1983, p. 1,463). Warmed air, which is less dense than the cold ambient outside air, is buoyed upward through the vertical (chimney) ducts and vents into the atmosphere. As long as the ambient air is colder than the ground, convection continues to remove thermal energy from the ground; however, when the temperature of the outside air equals or exceeds the ground temperature, airflow through the culverts stops. Thus, the cooling system is designed to become dormant each summer

Two of the five horizontal ducts north and south of highway centerline were instrumented with strings of thermistors and monitored to determine (1) whether the open-duct structure achieved the anticipated chilling of the fill, and (2) whether longitudinal ground cracking was reduced compared to an adjacent $~ 122$-m-long control segment east of the test section (Braley and others, 1991). Thermistors were placed on duct surfaces and in the fill at horizontal and vertical distances of $0.3,0.6$, and $1.2 \mathrm{~m}$ outward from the culverts. Inlet and outlet air temperatures were measured monthly from 04/20/1986 through 04/24/2005 with thermistors extending several centimeters into the northern duct. Using equations expressing (1) airflow energy balance through the open duct and (2) conductive heat transfer through the ground, Braley and others (1991) analyzed averaged temperature data collected monthly from 04/24/1985 through $04 / 10 / 1986$ in the northern instrumented duct, and estimated that 21.4 to $21.5 \times 10^{9}$ joules of heat were removed from the thick fill through that single northern duct each year.

To relate this heat loss to the performance of the thick highway fill and compare that performance with the performance of the road in the adjacent control section during the same period of time, an elevation survey of the road surface and embankment slopes was completed annually from June 1984 through September 1988. Settlement plates were also installed along three embankment cross sections: (1) in the control section, (2) near the eastern end of the duct section, and (3) near the center of the air-duct section. In the southern embankment, subsidence of the settlement plates was generally about twice as great as in the northern embankment, perhaps because of greater solar insolation, or because the former roadway underlies the northern embankment and earlier thaw-settlement may have partially stabilized the foundation soils there before the present highway fill was emplaced (Braley and others, 1991). Differential settlement was greatest $(-0.40 \mathrm{~m})$ in the control section in the southern embankment, and $-0.20 \mathrm{~m}$ of settling was measured in the northern embankment. Along the cross section in the center of the air-duct section, the maximum subsidence was $-0.14 \mathrm{~m}$ in the southern embankment and $-0.03 \mathrm{~m}$ in the northern embankment. Differential settlement in the duct section was 83-98 percent less than differential settlement in the control section, probably due to chilling of the highway fill by the open-duct system (Braley and others, 1991). In practical terms, the highway in the control section had to be resurfaced four times in the 5 years following construction, compared to only once in the duct section, and periodic resurfacing continues (fig. 14).

Thus, by the use of this duct system, embankment spreading and cracking problems were reduced but not eliminated (Esch, 1996, p. 134). Tension cracks parallel to the southern edge of the fill and water standing along the toe are evidence that ice-rich permafrost beneath the southern toe of the fill has partially thawed, causing subsidence and rotating the fill margin downward. 


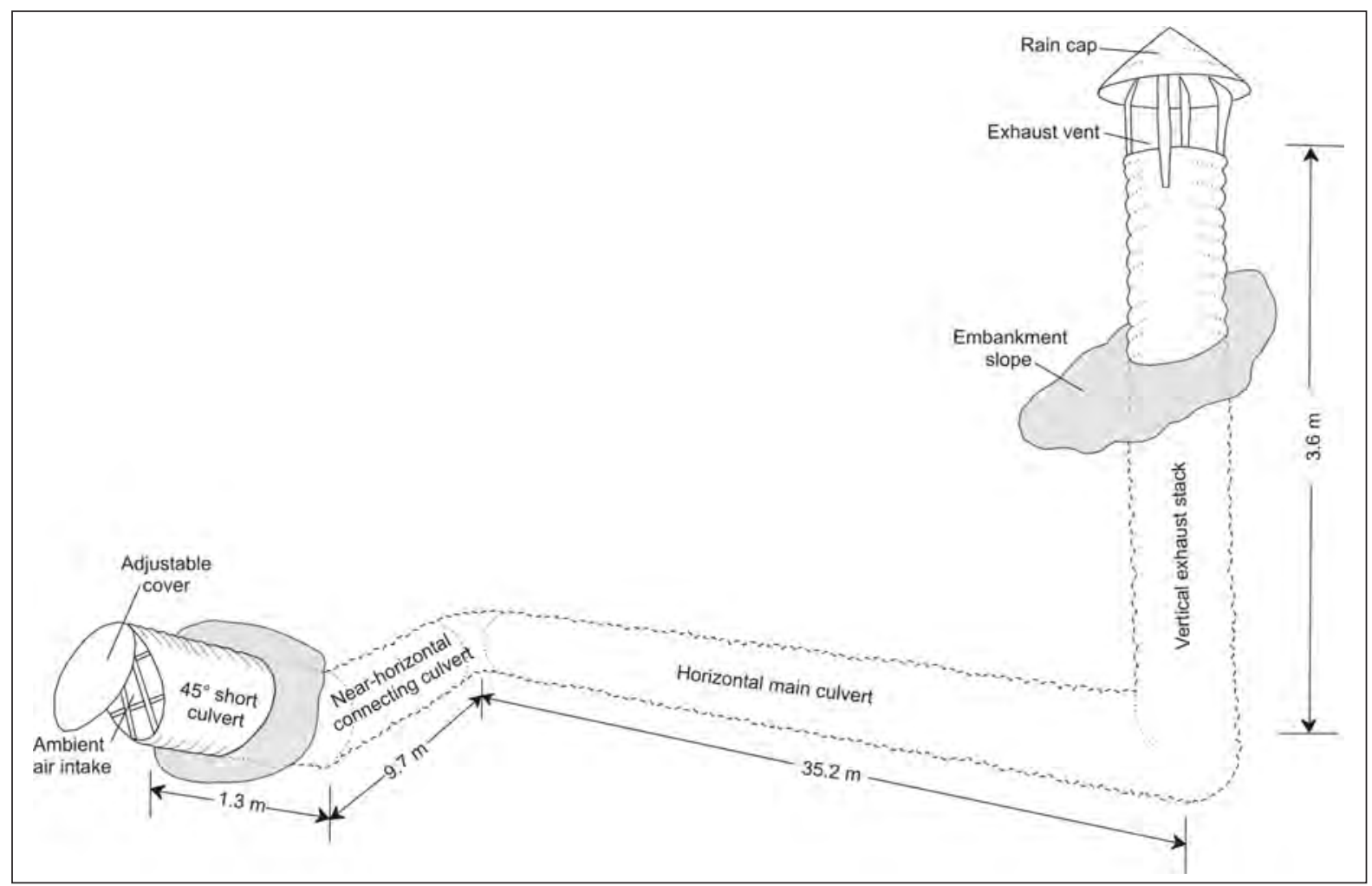

Figure 12. Sketch of culvert elements in one of ten open-duct systems installed in 1983 near the northern and southern margins of the thick road fill at Alaska Highway milepost 1240.3, southwestern Nabesna D-1 Quadrangle (modified from Braley and others, 1991, fig. 5).

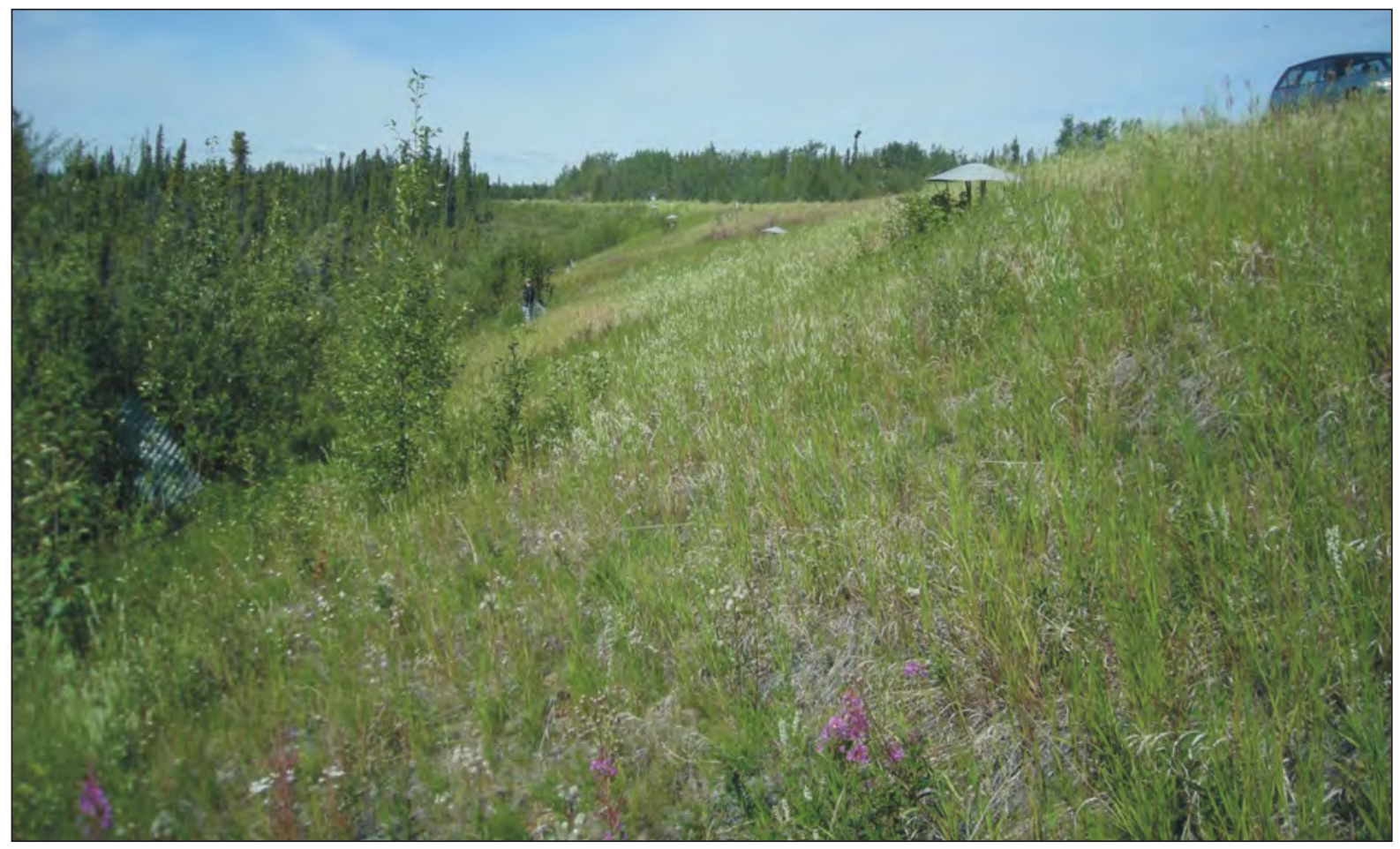

Figure 13. Vegetated southern flank of thick road fill at Alaska Highway milepost 1240.3, southwestern Nabesna D-1 Quadrangle, showing tops of vertical corrugated culverts and inclined end of horizontal culvert with adjustable metal cover. Person provides scale. Photograph taken 07/25/2009 by R.D. Reger. 


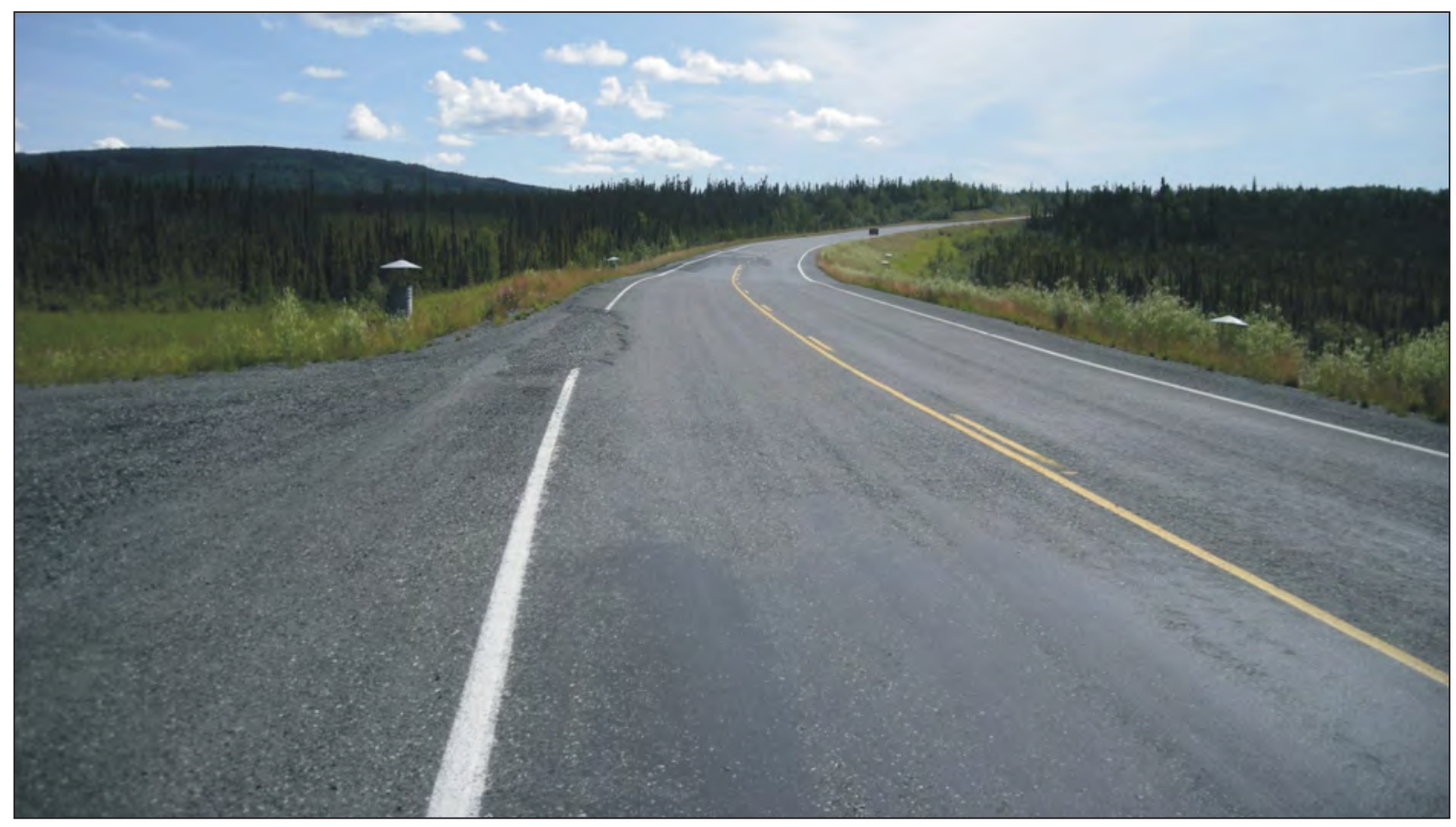

Figure 14. Damage to Alaska Highway caused by differential settlement of thick roadfill at milepost 1240.3. Note depression in white fog line in background. Photograph taken 07/25/2009 by R.D. Reger.

On 07/25/2009 when we examined the easternmost vertical stack in the northern embankment, ice was present at the level of the horizontal culvert, and ice was floating in water near the bottom of the easternmost vertical stack in the southern embankment, indicating that the culverts are inadequately drained and no longer function as effective cooling structures. Measurements of water levels in five piezometers near the ducts indicate that the sources of water entering the ducts were a high water table during the spring and infiltration from the embankment fill (Braley and others, 1991).

\section{SCOTTIE CREEK LOWLAND}

Expansion of the lower Chisana River fan has partially impounded the lower Scottie Creek drainage to the east, where high water tables are indicated by numerous thaw lakes interspersed throughout the swampy lowland and flooded meandering stream channels (fig. 15). In this western part of the Scottie Creek lowland, permafrost is mapped as sporadic to discontinuous with low to moderate ice content, depending on the density of thaw lakes and the presence or absence of polygonal ground (fig. 16) (sheet 2). This mapping is supported by EM1DFM inversion sections 15200 and 15290 (Burns and others, unpublished data). Helicopter observations of numerous thaw lakes in the Scottie Creek lowland confirmed that most shorelines are well vegetated and apparently stable. Only a few of the lakes in this lowland exhibit actively sloughing banks, locally scalloped shorelines, and tilted shoreline black spruce trees (fig. 17), indicating that fine-grained, ice-rich sediments are present and lake shores are only locally receding. Examination of EM1DFM inversion sections 15080 and 15081 (Burns and others, unpublished data) indicates that permafrost is absent under the larger thaw lakes and beneath swampy meandering stream courses (sheet 2).

In the valley of Desper Creek, a tributary of Scottie Creek, we map continuous permafrost with moderate to high ice content in retransported eolian sediments mixed with lowland loess and continuous permafrost with low to moderate ice content in colluvial-alluvial fans on lower slopes (sheet 2; Reger and others, in press). At the Desper Creek crossing by the Alaska Highway, the depth to permafrost in 1965 was $>5.2 \mathrm{~m}$ in the closed talik and ranged from 0.2 to $1.4 \mathrm{~m}$ outside of the talik (L.L. Morrison, 12/13/1965, written communication). Examination of EM1DFM inversion section 15290 (Burns and others, unpublished data) indicates that discontinuous permafrost with moderate to high ice content in that area is up to $\sim 58 \mathrm{~m}$ thick and is underlain by unfrozen, saturated, finegrained sediments (fig. 2). 


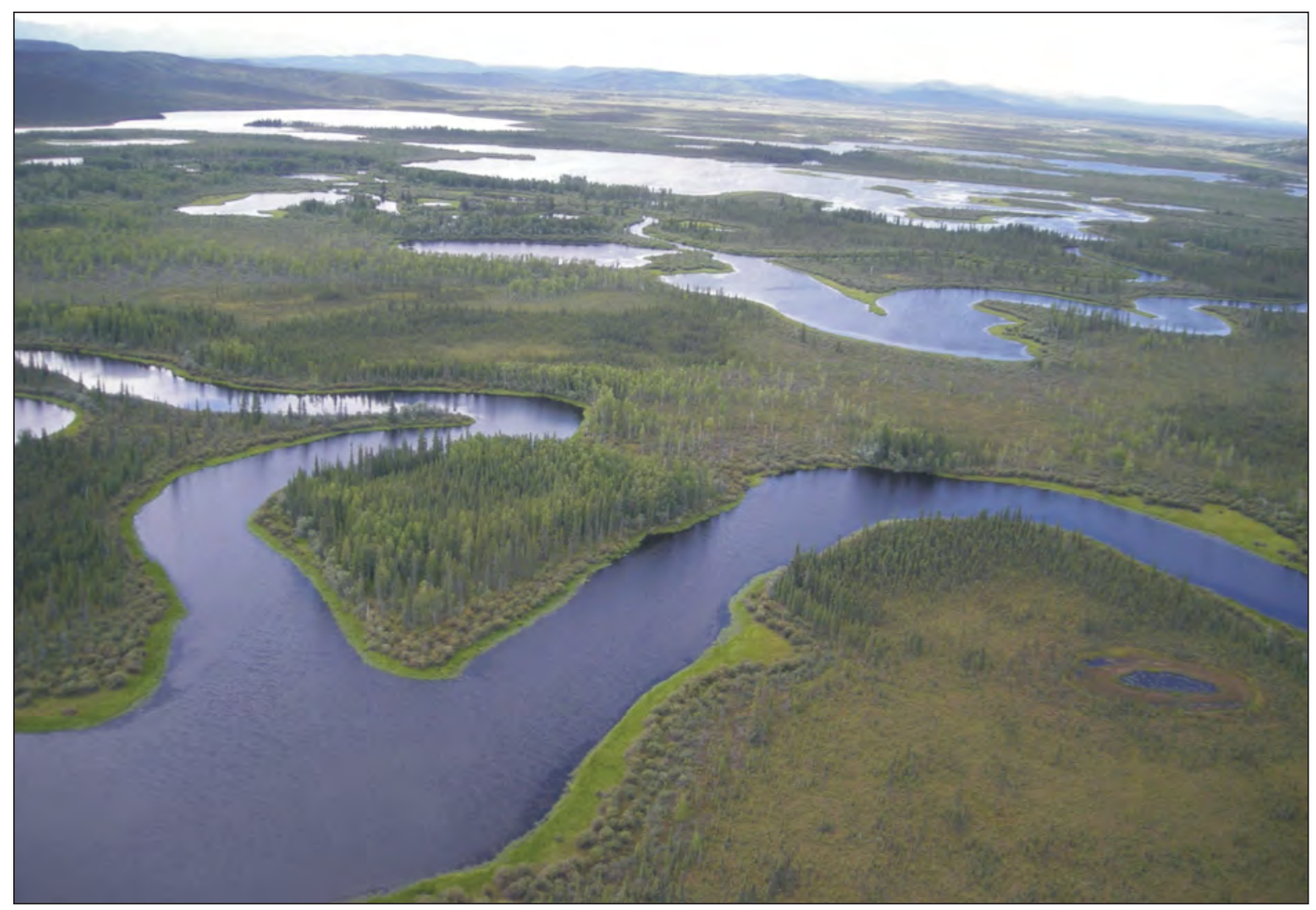

Figure 15. Aerial view toward west of numerous thaw lakes in Scottie Creek lowland, northwestern Nabesna C-1 Quadrangle. Flooded channel of Scottie Creek in foreground reflects flood stage of nearby Chisana River. Photograph taken 07/22/2009 by R.D. Reger.

At the Scottie Creek crossing by the Alaska Highway in August 1992 (sheet 2), five boreholes drilled to depths of 27 to $35 \mathrm{~m}$ penetrated up to $31 \mathrm{~m}$ of silt and sandy silt with thin interbeds of fine-grained organic material (Hemenway, 1994) ${ }^{8}$. Beneath $3.9 \mathrm{~m}$ of surface gravel fill, the boreholes documented continuous permafrost with ground ice that varied from 60 percent (by volume) thin segregations and randomly oriented veins up to $1.9 \mathrm{~cm}$ thick to well bonded silt with no visible ice. A vertical temperature profile measured on 10/29/1982 to a total depth of $12.8 \mathrm{~m}$ in silt and sandy silt beneath the south bridge abutment in the closed talik along the stream documented permafrost temperatures from $-0.6^{\circ}$ to $-0.3^{\circ} \mathrm{C}$ between depths of 1.8 and $12.8 \mathrm{~m}$. A more reliable record of the permafrost temperature in the Scottie Creek lowland was collected by Mike Metz outside the talik influence at Alaska

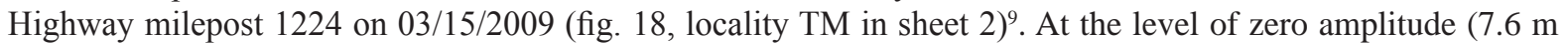
deep) the ground temperature was $-2.1^{\circ} \mathrm{C}$. This temperature indicates that permafrost in that area is discontinuous. Examination of EM1DFM inversion section 15290 (Burns and others, unpublished data) confirms the presence of discontinuous permafrost and indicates that permafrost in this part of the lowland is $<\sim 75 \mathrm{~m}$ thick (fig. 2).

In the largest tributary valley on the northern flank of the highlands south of Scottie Creek in the northeastern Nabesna C-1 Quadrangle (fig. 18), broad, low mounds with circular to ellipsoidal outlines are associated with retransported eolian sediments that are complexly mixed with lowland loess and vegetated by dense black spruce. Our brief field investigations to determine if these mounds are palsas or peat plateaus ${ }^{10}$ determined that no peat

${ }^{8}$ These thick, fine-grained sediments could overlie and interfinger with slackwater-basin deposits laid down by massive floods flowing down the Chisana River during the last major glaciation. However, we do not recognize surface evidence of massive outburst floods upstream of the Tok fan in the upper Tanana River valley. Although Duk-Rodkin and others (2002) extend middle Pleistocene glaciation in the Chisana River drainage into the lower Scottie Creek drainage and show a glacier-impounded lake there, we recognize no surface evidence there for either the glaciation or the ice-impounded lake.

${ }^{9}$ The installation at $1,875 \mathrm{ft}(560 \mathrm{~m})$ elevation $\left(62^{\circ} 38^{\prime} 30.9^{\prime} \mathrm{N}, 141^{\circ} 01^{\prime} 48.6^{\prime \prime} \mathrm{W}\right)$ records temperature every 20 minutes and averages the temperature four times daily (Mike Metz, 05/12/2009, written communication).

${ }^{10}$ Ice-rich, perennially frozen mounds or low tablelands composed primarily of peat with layered ground ice lenses and layers (Lundqvist, 1969; Zoltai and Tarnocai, 1975). 


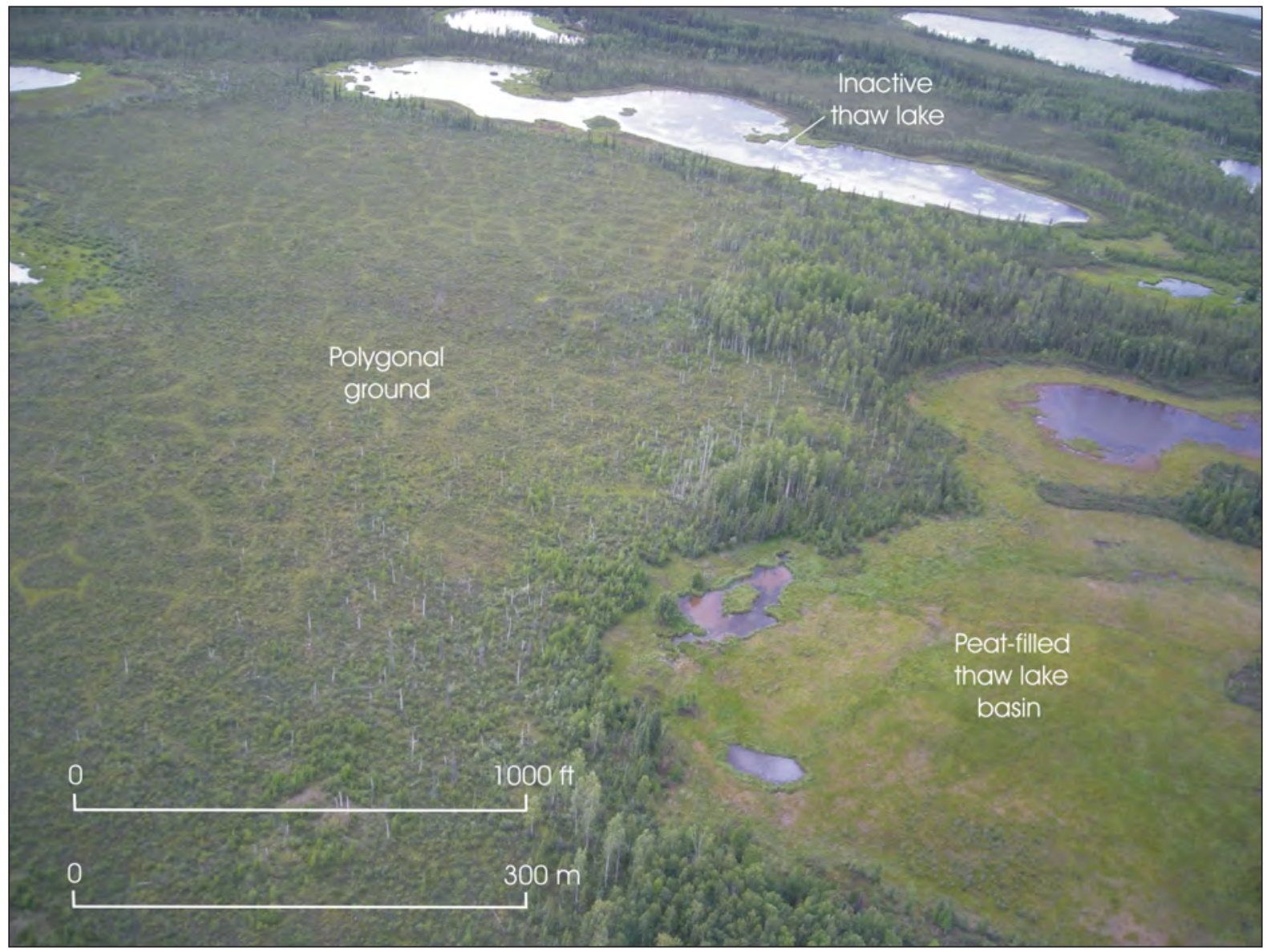

Figure 16. Aerial view of inactive thaw lake, peat-filled thaw lake basin, and polygonal ground, Scottie Creek lowland, northwestern Nabesna C-1 Quadrangle. Photograph taken 07/22/2009 by R.D. Reger.

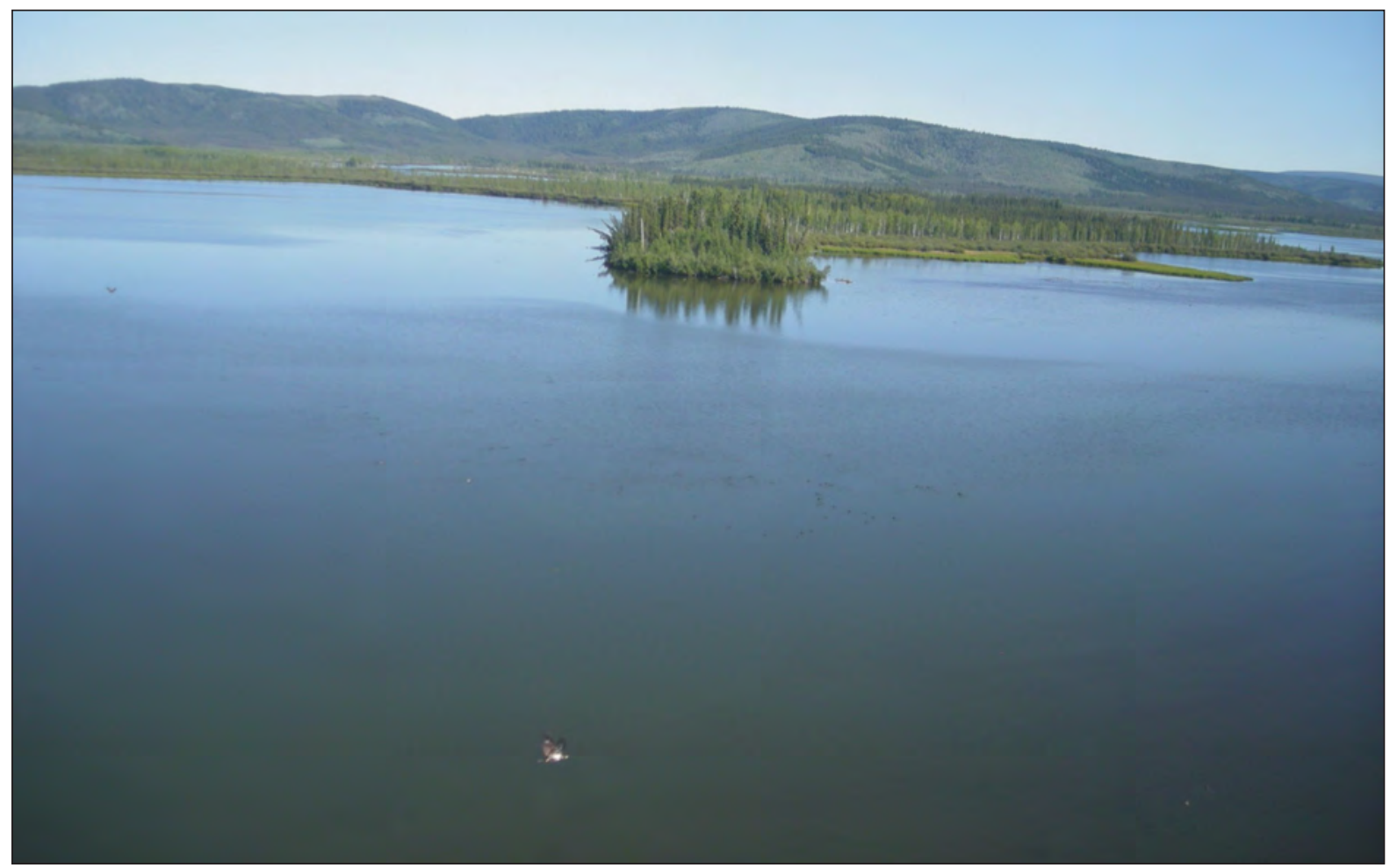

Figure 17. Black spruce trees tilted into large thaw lake by active bank recession, Scottie Creek lowland, northwestern Nabesna C-1 Quadrangle. Photograph taken 07/25/2009 by R.D. Reger. 


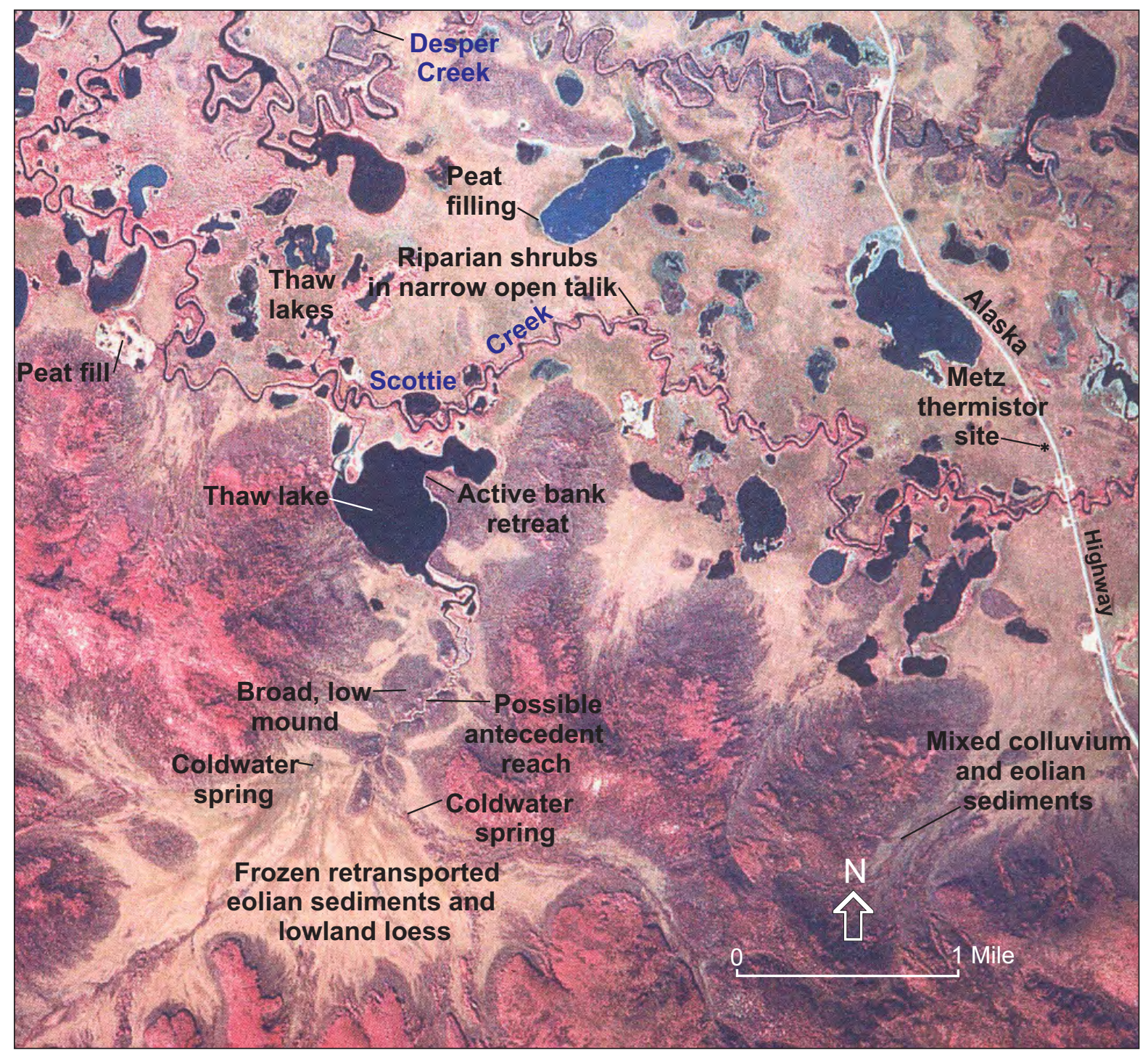

Figure 18. Vertical aerial view of features related to ground ice in permafrost, Scottie Creek lowland (Alaska High Altitude Photograph ALK 60 CIR 4111 taken August 1981).

is present on the low mounds. Although there was no evidence that the area had recently burned, many of the closely spaced black spruce trees and scattered paper birch and dead balsam poplar trees were tilted and down (fig. 19). The groundcover is a continuous, 15 -cm-thick mat of feathermosses. At the crest of the broad mound we investigated, the 18-cm-thick active layer beneath the organic mat is composed of dark grayish brown (2.5Y4/2), slightly thixotropic, inorganic clayey silt with a trace of very fine sand. The perennially frozen sandy silt beneath is well bonded and contains no visible ice. The difference in elevation is $5 \mathrm{~m}$ between the crest of that mound and the nearby floodplain of a small, spring-fed stream. The course of this small stream across the mound indicates an antecedent origin in which the mound rose after the stream course was established, perhaps due to the development of ground ice in aggrading permafrost. However, we found no evidence for mound dilation, such as radially tilted trees, radial ground cracks, or springs emerging from the mound. The lack of peat or evidence for massive ground ice and dilation or collapse indicates that the low mound is likely a frozen dune.

On the other hand, there are signs that shallow permafrost is actively degrading, at least locally, in that tributary valley. Probe measurements in the tussock-covered valley bottom around the mounds indicate that the general depth to permafrost is $\sim 30$ to $35 \mathrm{~cm}$. The channel of the small, spring-fed stream across the mound we investigated has been widened by thermokarst processes (fig. 18). A nearby tributary to that stream, which drains from a different neighboring spring, follows an angular course associated with small mounds (fig. 20) that indicate the presence of 


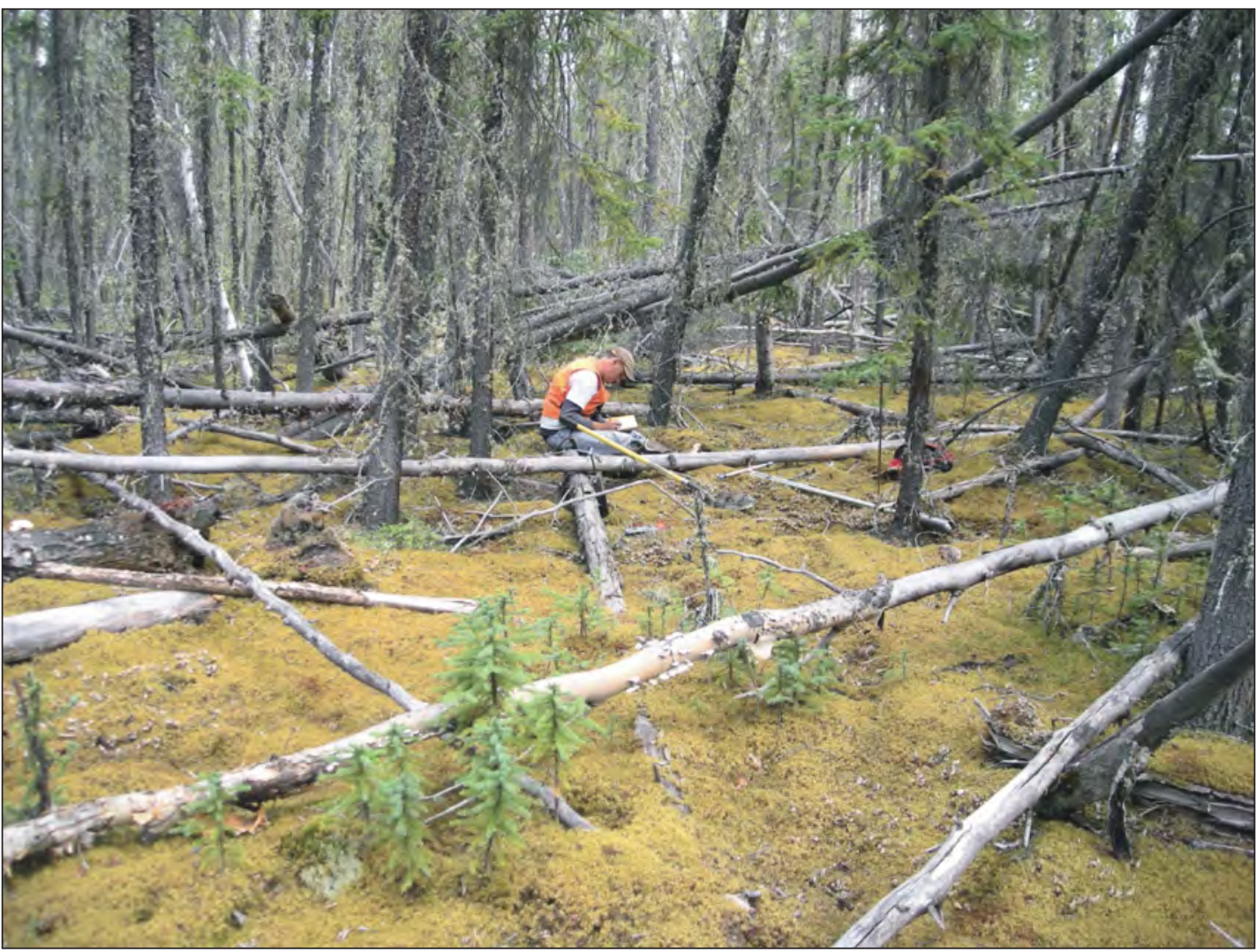

Figure 19. Dense black spruce forest with numerous tilted and downed trees on crest of low mound of perennially frozen, retransported sandy silt, northeastern Nabesna C-1 Quadrangle. Ground cover is a thick mat offeathermosses. Person provides scale. Photograph taken 07/22/2009 by R.D. Reger.

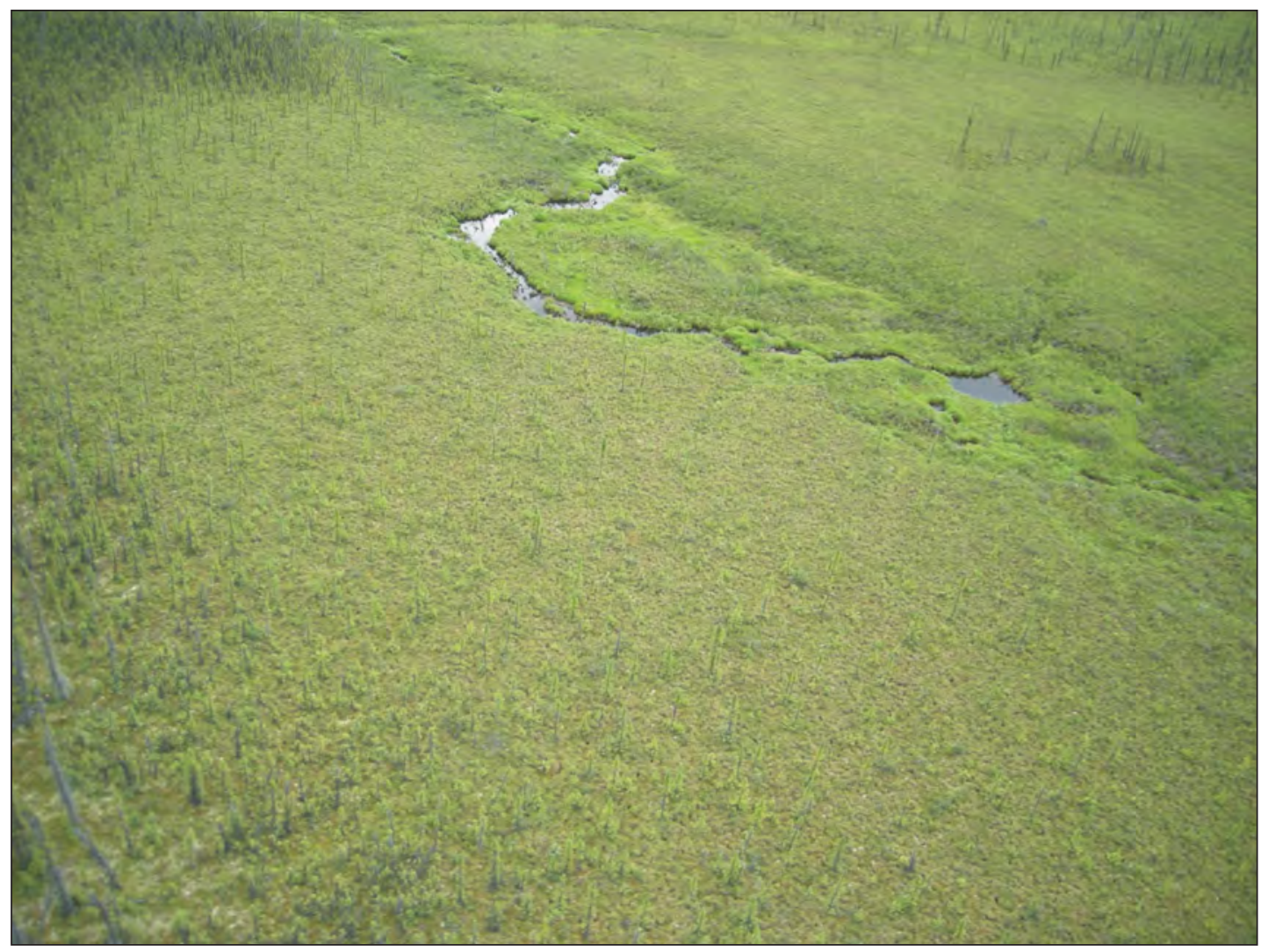

Figure 20. Aerial view of spring source of small stream draining tussock-covered lowland of perennially frozen, retransported sandy eolian silt, northeastern Nabesna C-1 Quadrangle. Angular stream course around low mounds indicates stream follows ice-wedge polygons. Photograph taken 07/22/2009 by R.D. Reger. 
polygonal ice wedges in the fine-grained valley fill. Thawing of permafrost along this small branch has lowered the stream channel 1.5 to $2 \mathrm{~m}$ below the surrounding land surface, causing trees along the banks to tilt and fall chaotically into the small stream valley (fig. 21). Trough-shaped, linear cracks parallel to the nearby edges of the shallow stream valley and tilted trees demonstrate that 30-cm-thick active-layer detachment slides (Huscroft and others, 2004; Lipovsky and others, 2006) are displaced toward the gully from the upland on the thawing permafrost. In the 2-m-high wall of a short, linear tributary gully, massive, micaceous, dark gray (5Y4/1), very fine to fine sand with a trace of silt is exposed in the valley fill. Depth to permafrost is $42 \mathrm{~cm}$ beneath the $\mathbf{V}$-shaped bottom of that gully and $>84 \mathrm{~cm}$ behind the gully walls. The chaotic piles of trees in the gully, turf mats draped over the upper gully sides, thin detachment failures, and blocks of massive fine sand at the base of the gully walls are evidence that the gully has a thermokarst origin.

\section{MIRROR CREEK LOWLAND}

Examination of EM1DFM inversion sections 15230 and 15290 (Burns and others, unpublished data) indicates that the Mirror Creek lowland near the southern limit of the Yukon-Tanana Upland is underlain by sporadic permafrost with low to moderate ice content. However, in fluvial-colluvial fans along the margins of the lowland, discontinuous permafrost with low to moderate ice content is apparently up to $\sim 45 \mathrm{~m}$ thick (sheet 2).

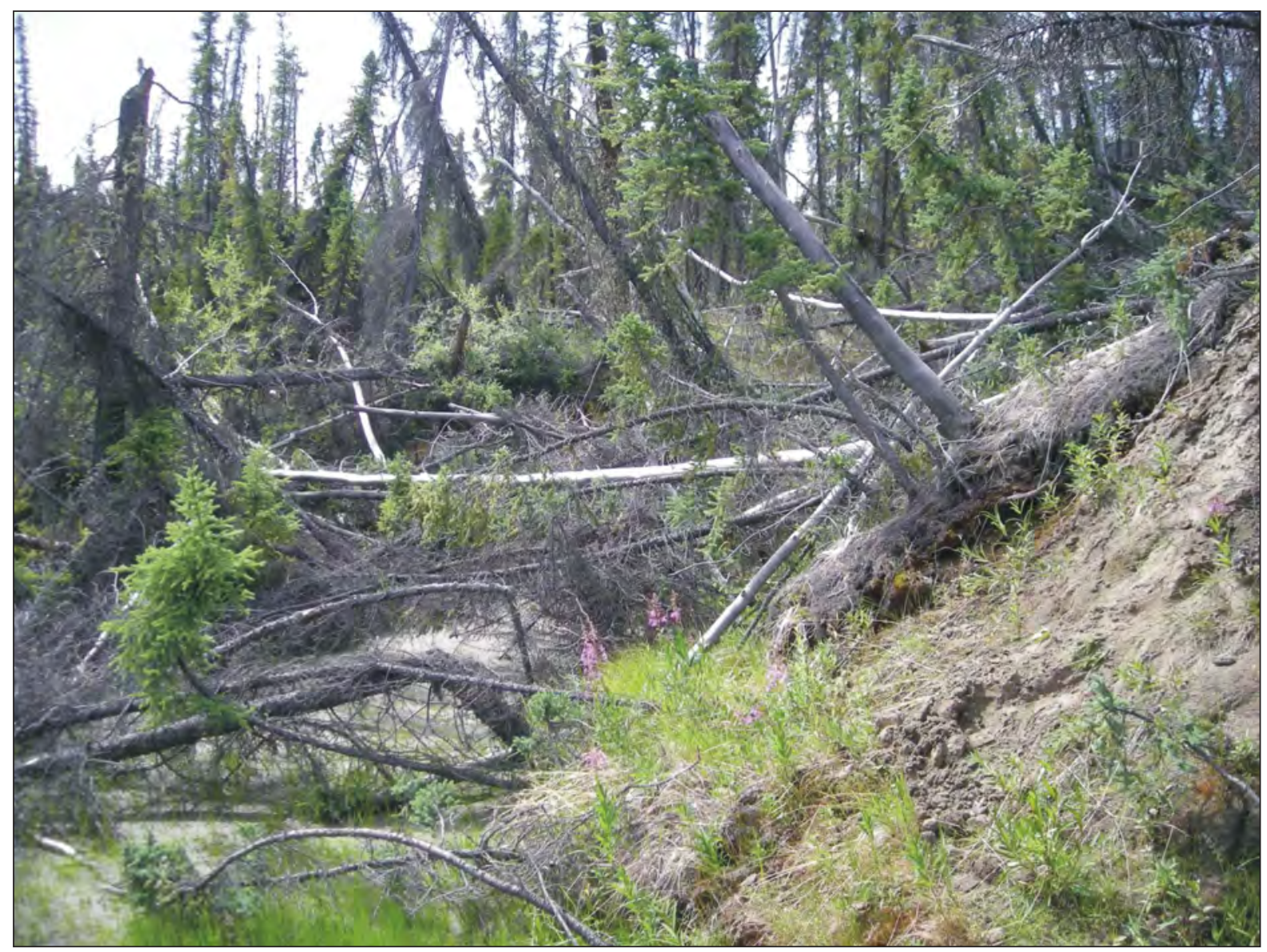

Figure 21. Chaotic black spruce and scattered, dead balsam poplar trees in thermokarst-modified channel of small stream in northeastern Nabesna C-1 Quadrangle. Tilted black spruce trees on turf mats settled onto channel walls when perennially frozen; retransported sandy eolian silt thawed and sloughed into drainageway (foreground). Photograph taken 07/22/2009 by R.D. Reger. 


\section{ACKNOWLEDGMENTS}

Most of the background knowledge for this permafrost interpretation was assimilated during preconstruction geotechnical investigations for the trans-Alaska oil pipeline system (Kreig and Reger, 1976, 1982), and we gratefully acknowledge the vital support and contributions made during those investigations by Alyeska Pipeline Service Company, R \& M Consultants Inc., and especially Mike Metz and Ray Kreig. We particularly thank Mike Metz for sharing the summary of ground-temperature data he recorded at milepost 1224 Alaska Highway. Jim Sweeney, Alaska Department of Transportation \& Public Facilities in Fairbanks, kindly provided a copy of the final report evaluating the milepost 1240 experimental open-duct structure.

Several colleagues in the field and in Fairbanks provided assistance, references, samples, photographs, editing, and stimulating discussions, including (in alphabetical order) Laurel Burns, Rod Combellick, Paula Davis, Angie Floyd, Larry Freeman, Rich Koehler, Rainer Newberry, Joyce Outten, Joni Robinson, Diana Solie, Fred Sturmann, Rhea Supplee, Dave Szumigala, Melanie Werdon, James Weakland and Rachel Westbrook. Daily feedback from geologists mapping the bedrock was particularly helpful for confirming the distribution of bedrock exposures and shallow bedrock and the presence or absence of frozen ground along their traverses. We thank De Anne Stevens for creating the location map for this third corridor segment. Meg Hayes helped us coordinate with local Native organizations, and we greatly appreciate permission to access private lands owned by Doyon Limited, Northway Natives Inc., and the Tetlin Native Corporation. We are also grateful to the U.S. Fish and Wildlife Service for granting us access to the Tetlin Wildlife Refuge. Karen Johnson provided inspired meals that kept our crew energized in the field. Helicopter pilots Bill Snyder and Al Holzman safely delivered us to and from remote field sites each day the weather permitted us to fly. The thoughtful technical review by M. Torre Jorgenson particularly helped us clarify our presentation. Funding for this project was provided by the State of Alaska.

\section{REFERENCES}

Abbott, M.B., and Stafford, T.W., Jr., 1996, Radiocarbon geochemistry of modern and ancient arctic lake systems, Baffin Island, Canada: Quaternary Research, v. 45, no. 3, p. 300-311.

Braley, Alan, Connor, Billy, Reckard, Matthew, and Zarling, J.P., 1991, Evaluation of Gardiner Creek air ducts: Alaska Department of Transportation \& Public Facilities Report FHWAAKRD9108, 30 p.

Burns, L.E., Fugro Airborne Surveys Corp., and Stevens Exploration Management Corp., 2006, Line, grid, and vector data, and plot files for the airborne geophysical survey of the Alaska Highway corridor, east-central Alaska: Alaska Division of Geological \& Geophysical Surveys Geophysical Report 2006-6, 1 DVD.

Chapin, F.S., III, Viereck, L.A., Adams, P.C., Van Cleve, Keith, Fastie, C.L., Ott, R.A., Mann, Daniel, and Johnston, J.F., 2006, Successional processes in the Alaskan boreal forest, in Chapin, F.S., III, Oswood, M.W., Van Cleve, Keith, Viereck, L.A., and Verbyla, D.L., eds., Alaska’s changing boreal forest: Oxford, England, Oxford University Press, p. 100-120.

Duk-Rodkin, Alejandra, Weber, Florence, and Barendregt, R.W., 2002, Glacial limits of upper Yukon River: Geological Survey of Canada Open File 4275, 1 sheet, scale 1:1,000,000.

Esch, D.C., 1988, Embankment case histories on permafrost, in Johnson, E.G., ed., Embankment design and construction in cold regions: New York, American Society of Civil Engineers/ Technical Council on Cold Regions Engineering monograph, p. 127-159.

1996, Road and airfield design for permafrost conditions, in Vinson, T.S., Rooney, J.W., and Haas, W.H., eds., Roads and airfields in cold regions: New York, Technical Council on Cold Regions Engineering monograph, p. 121-149.

Ferrians, O.J., Jr., 1965, Permafrost map of Alaska: U.S. Geological Survey Miscellaneous Geologic Investigations Map I-445, 1 plate, scale 1:2,500,000.

-1988, Pingos in Alaska_A review, in Senneset, K., ed., Permafrost, Fifth International Conference Proceedings: Trondheim, Norway, Tapir Publishers, p. 734-739.

Ferrians, O.J., Jr., Kachadoorian, Reuben, and Greene, G.W., 1969, Permafrost and related engineering problems in Alaska: U.S. Geological Survey Professional Paper 678, 37 p.

French, H.M., 2007, The periglacial environment: Chichester, England: John Wiley \& Sons, Ltd., 458 p.

Hemenway, K.T., 1994, Scottie Creek bridge (No. 501) replacement, Alaska Highway MP 1222-North (Project No. IM-OA1-1(9): Alaska Department of Transportation \& Public Facilities foundation report, 20 p.

Hinzman, L.D., Viereck, L.A., Adams, P.C., Romanovsky, V.E., and Yoshikawa, Kenji, 2006, Climate and permafrost dynamics of the Alaskan boreal forest, in Chapin, F.S., III, Oswood, M.W., Van Cleve, Keith, Viereck, L.A., and Verbyla, D.L., eds., Alaska's changing boreal forest: Oxford, England, Oxford University Press, p. 39-61. 
Holmes, G.W., Hopkins, D.M., and Foster, H.L., 1968, Pingos in central Alaska: U.S. Geological Survey Bulletin 1241-H, 40 p.

Hopkins, D.M., Karlstrom, T.N.V., Black, R.F., Williams, J.R., Péwé, T.L., Fernald, A.T., and Muller, E.H., 1955, Permafrost and ground water in Alaska: U.S. Geological Survey Professional Paper 264-F, p. 113-146.

Huscroft, C.A., Lipovsky, P.V., and Bond, J.D., 2004, A regional characterization of landslides in the Alaska Highway corridor, Yukon: Yukon Geological Survey Open File 2004-18, 65 p. (with CD-ROM).

Jorgenson, M.T., and Osterkamp, T.E., 2005, Response of boreal ecosystems to varying modes of permafrost degradation: Canadian Journal of Forestry Research, v. 35, p. 2,100-2,111.

Jorgenson, M.T., and Racine, C.H., 2001, Review of potential impacts of the proposed GVEA powerline on ecosystems on the Tanana Flats: Final report prepared for Alaska Division of Mining, Land, and Water by ABR, Inc., Fairbanks, 24 p.

Jorgenson, M.T., Racine, C.H., Walters, J.C., and Osterkamp, T.E., 2001, Permafrost degradation and ecological changes associated with a warming climate in central Alaska: Climatic Change, v. 48, p. 551-579.

Jorgenson, M.T., Yoshikawa, Kenji, Kanevskiy, Mikhail, Shur, Yuri, Romanovsky, Vladimir, Marchenko, Sergei, Grosse, Guido, Brown, Jerry, and Jones, Ben, 2008, Permafrost characteristics of Alaska, in Kane, D.L., and Hinkel, K.M., eds., Proceedings of the Ninth International Conference on Permafrost, Fairbanks, Alaska, University of Alaska Fairbanks, p. 121-122.

Kreig, R.A., and Reger, R.D., 1976, Preconstruction terrain evaluation for the trans-Alaska pipeline project, in Coates, D.R., ed., Geomorphology and engineering: Stroudsburg, Dowden, Hutchinson, and Ross, p. 55-76.

1982, Air-photo analysis and summary of landform soil properties along the route of the Trans-Alaska Pipeline System: Alaska Division of Geological \& Geophysical Surveys Geologic Report 66, 149 p.

Lipovsky, P.S., Coates, Jim, Lewkowicz, A.G., and Trochim, Erin, 2006, Active-layer detachments following the summer 2004 forest fires near Dawson City, Yukon, in Edmond, D.S., Bradshaw, G.D., Lewis, L.L., and Weston, L.H., eds., Yukon exploration and geology 2005: Yukon Geological Survey report, p. 175-194.

Lundqvist, Jan, 1969, Earth and ice mounds: A terminological discussion, in Péwé, T.L., ed., The periglacial environment, past and present: Montreal, McGill-Queen's University Press, p. 203-215.

Muller, S.W., 1947, Permafrost or permanently frozen ground and related engineering problems: Ann Arbor, Michigan, J.W. Edwards, Inc., 231 p.

Murton, J.B., 1996, Thermokarst-lake basin sediments, Tuktoyaktuk coastlands, western arctic Canada: Sedimentology, v. 43, p. 737-760.

Nelson, R.E., Carter, L.D., and Robinson, S.W., 1988, Anomalous radiocarbon ages from a Holocene detrital organic lens in Alaska and their implications for radiocarbon dating and paleoenvironmental reconstruction in the Arctic: Quaternary Research, v. 29, no. 1, p. 66-71.

Osterkamp, T.E., and Romanovsky, V.E., 1999, Evidence for warming and thawing of discontinuous permafrost in Alaska: Permafrost and Periglacial Processes, v. 10, p. 17-37.

Péwé, T.L., 1954, Effect of permafrost on cultivated fields, Fairbanks area, Alaska: U.S. Geological Survey Bulletin 989-F, p. 315-351.

1970, Permafrost and vegetation on floodplains of subarctic rivers (Alaska), a summary, in Ecology of the subarctic regions_-Proceedings of the Helsinki symposium: UNESCO, p. 141-142.

1982, Geologic hazards of the Fairbanks area, Alaska: Alaska Division of Geological \& Geophysical Surveys Special Report 15, 109 p.

Racine, C.H., and Walters, J.C., 1994, Groundwater-discharge fens in the Tanana lowlands, interior Alaska, U.S.A.: Arctic and Alpine Research, v. 26, no. 4, p. 418-426.

Reger, R.D., and Hubbard, T.D., 2010a, Reconnaissance interpretation of 1978-1983 permafrost, Alaska Highway Corridor, Robertson River to Tetlin Junction, Alaska: Alaska Division of Geological \& Geophysical Surveys Preliminary Interpretive Report 2009-6C, 13 p., 4 sheets, scale 1:63,360.

Reger, R.D., and Hubbard, T.D., 2010b, Engineering geologic map, Alaska Highway corridor, Robertson River to Tetlin Junction, Alaska: Alaska Division of Geological \& Geophysical Surveys Preliminary Interpretive Report 2009-6B, 4 sheets, scale 1:63,360.

Reger, R.D., and Solie, D.N., 2008a, Engineering geologic map, Alaska Highway corridor, Delta Junction to Dot Lake, Alaska: Alaska Division of Geological \& Geophysical Surveys Preliminary Interpretive Report 20083B, 2 sheets, scale 1:63,360. 
Reger, R.D., Hubbard, T.D., and Carver, G.A., 2008b, Reconnaissance interpretation of permafrost, Alaska Highway corridor, Delta Junction to Dot Lake, Alaska: Alaska Division of Geological \& Geophysical Surveys Preliminary Interpretive Report 2008-3C, 10 p., 2 sheets, scale 1:63,360.

Reger, R.D., Hubbard, T.D., and Carver, G.A., 2011, Surficial geology of the Alaska Highway Corridor, Robertson River to Tetlin Junction, Alaska: Alaska Division of Geological \& Geophysical Surveys Preliminary Interpretive Report 2009-6A, 4 sheets, scale 1:63,360.

Reger, R.D., Hubbard, T.D., and Gallagher, P.E., in press, Surficial geology of the Alaska Highway Corridor, Tetlin Junction to Canada border, Alaska: Alaska Division of Geological \& Geophysical Surveys Preliminary Interpretive Report 2012-1A, 26 p., 2 sheets, scale 1:63,360.

Reger, R.D., Stevens, D.S.P., and Solie, D.N., 2008, Surficial geology of the Alaska Highway corridor, Delta Junction to Dot Lake, Alaska: Alaska Division of Geological \& Geophysical Surveys Preliminary Interpretive Report 2008-3A, 48 p., 2 sheets, scale 1:63,360.

Sengpiel, K.P., 1988, Approximate inversion of airborne EM data from multilayered ground: Geophysical Prospecting, v. 36, p. 446-459.

Solie, D.N., and Burns, L.E., 2006, Geology, geophysics and geohazards along the Alaska Highway corridor-A project of the Alaska Division of Geological \& Geophysical Surveys [poster]: 34th Yukon Geoscience Forum, Whitehorse, November 26-29.

2007, Alaska Highway Corridor geology and geophysics: Alaska GeoSurvey News, v. 10, no. 1, p. 1-4.

Wallace, R.E., 1948, Cave-in lakes in the Nabesna, Chisana, and Tanana river valleys, eastern Alaska: Journal of Geology, v. 56, no. 3, p. 171-181.

Weber, F.R., and Péwé, T.L., 1961, Engineering geology problems in the Yukon-Koyukuk lowland, Alaska, in Short Papers in the Geologic and Hydrologic Sciences 1961: U.S. Geological Survey Professional Paper 424D, p. 371-373.

1970, Surficial and engineering geology of the central part of the Yukon-Koyukuk lowland, Alaska: U.S. Geological Survey Miscellaneous Geologic Investigations Map I-590, 2 sheets, scale 1:125,000.

Williams, J.R., 1970, Ground water in the permafrost regions of Alaska: U.S. Geological Survey Professional Paper 296, 83 p.

Zarling, J.P., Connor, Billy, and Goering, D.J., 1983, Air duct systems for roadway stabilization over permafrost areas, in Proceedings of the 4th International Conference on Permafrost, Washington, D.C., National Academy Press, p. 1,463-1,468.

Zoltai, S.C., and Tarnocai, C., 1975, Perennially frozen peatlands in the western Arctic and Subarctic of Canada: Canadian Journal of Earth Sciences, v. 12, p. 28-43. 